\title{
Cutting the Gordian Knot: Turkish Foreign Policy Towards Cyprus During AK Party Era (2002-2020)
}

\section{Przecięcie węzła gordyjskiego: Turecka polityka zagraniczna względem Cypru w trakcie rządów AKP - Partii Sprawiedliwości i Rozwoju (2002-2020)}

\begin{abstract}
Cyprus Dispute is one of the fundamental foreign policy issues in Turkish foreign policy since the 1950s. Cyprus Dispute has often been perceived as an issue above petty politics in Turkey, and almost all Turkish political parties supported the Turkish State's involvement in Cyprus since the 1960s and Cyprus Peace Operation in 1974. However, after AK Party came to power in 2002, with the main motive of preventing a secular nationalist military coup, as well as with the aim of becoming a full member of the European Union (EU), the party adopted a proactive foreign policy favoring the solution in the island. That is why Turkey and Turkish Cypriots actively supported the Annan Plan referendum in 2004. However, upon the rejection of the settlement plan by Greek Cypriots and EU's decision to accept Greek Cypriot government as an EU member and the only representative of the Cyprus Republic, Cyprus Dispute has transformed into a problem spoiling not only Turkish-Greek and Turkish-Cypriot relations but also Turkish-EU relations. In the 2010s, the Cyprus Dispute gained a new dimension with the gas discoveries and agreements made by the Greek Cypriot administration. So far, energy politics could not be used as a leverage to promote the solution on the island, and the dispute has transformed into a more complex problem with many layers.
\end{abstract}

Keywords: AK Party, Cyprus Dispute, Energy Politics, Cyprus Republic, Turkish Republic of Northern Cyprus, Eastern Mediterranean

Abstrakt: Spór cypryjski jest jednym z najważniejszych zagadnień w tureckiej polityce zagranicznej od lat pięćdziesiątych. Jest on przeważnie postrzegany jako sprawa ponad

1 Dr Ozan ÖRMECİ, Political Science and Public Administration Department, Istanbul Gedik University, e-mail: ozan.ormeci@gedik.edu.tr/ozanormeci@gmail.com

2 Dr Sina KISACIK, Institute of Social Sciences, Istanbul Özyeğin University, e-mail: sina1979@hotmail.com 
podziałami politycznymi i prawie wszystkie tureckie partie polityczne popieraja zaangażowanie państwa tureckiego na Cyprze od lat sześćdziesiątych i od cypryjskiej operacji pokojowej w 1974 roku. Jednakże, po tym jak Partia AK (Partia Sprawiedliwości i Rozwoju) doszła do władzy w 2002 roku, z głównym motywem zapobieżenia świeckiego narodowego zamachu stanu, jak również mając na celu osiagnięcie petnego członkostwa w Unii Europejskiej, partia ta przyjęta pro-aktywna politykę zagraniczna sprzyjajaca rozładowaniu sytuacji na tej wyspie. Wtaśnie dlatego Turcja i tureccy Cypryjczycy aktywnie poparli referendum w ramach planu Annana w 2004 roku. Jednakże po odrzuceniu planu ugody przez greckich Cypryjczyków i po decyzji Unii Europejskiej o zaakceptowaniu rzadu grecko-cypryjskiego jako członka UE i jedynego reprezentanta Republiki Cypru w tej wspólnocie, spór cypryjski stał się problemem psującym stosunki nie tylko turecko-cypryjskie i grecko-cypryjskie, ale również te pomiędzy Turcją a Unia Europejska. W2010 roku, wraz z odkryciem złóż gazu ziemnego i porozumieniami zawartymi przez administracje grecko-cypryjska, konflikt cypryjski nabrat nowego wymiaru. Jak dotad polityka energetyczna nie mogła być użyta jako instrument w promowaniu rozwiazania na wyspie, tymczasem spór przekształcit się w o wiele bardziej skomplikowany problem, z wieloma wymiarami.

Słowa kluczowe: Partia Sprawiedliwości i Rozwoju, Spór Cypryjski, Polityka energetyczna, Republika Cypru, Turecka Republika Pótnocnego Cypru, Wschodnie Morze Śródziemne

\section{Introduction}

Cyprus Dispute is one of the top priority issues in Turkish foreign policy since the 1950s. Cyprus Dispute is perceived as an issue above party politics in Turkey. However, when Islamist-originated AK Party (Justice and Development Party) came to power in 2002, with the main motive of preventing a secular nationalist military coup, as well as with the aim of becoming a full member of the EU, the party adopted a proactive foreign policy favoring federal solution in the island. That is why; Turkey and Turkish Cypriots actively supported the Annan Plan referendum in 2004. However, upon the rejection of the settlement plan by Greek Cypriots and the EU's decision to accept the Greek Cypriot government as an EU member, Cyprus Dispute has transformed into a problem spoiling not only Turkish-Greek and Turkish-Cypriot relations, but also Turkish-EU relations. In the 2010s, the Cyprus Dispute gained a new dimension with the gas discoveries and agreements made by the Greek Cypriot administration. So far, energy politics could not be used as a leverage to promote the solution on the island, and the dispute has transformed into a more 
complex problem with many layers. Thus, it would not be wrong to claim that the Gordian $\mathrm{Knot}^{3}$ still exists, and Cyprus Dispute could be the source of new tensions in the Eastern Mediterranean (Encyclopedia Britannica; Andrews 2018).

This article aims to analyze Turkish foreign policy towards Cyprus during the AK Party era (2002-2020). To do that, first of all, Turkish foreign policy towards Cyprus will be explained with a particular focus on the ongoing AK Party era (2002-2020). In this part, the AK Party's Cyprus policy will also be categorized into different periods, and different parameters of the Cyprus Dispute will be revealed. In the second and the last part, the article will focus on the recent developments in the Eastern Mediterranean, especially in the field of energy politics, as well as these developments' effects over the Cyprus Dispute. The article will be mostly based on Turkish sources and will try to reflect the Turkish perspective over the problem.

\section{Turkish Foreign Policy Towards Cyprus During AK Party Era (2002-2020)}

\subsection{Turkish Foreign Policy and Cyprus Dispute}

Cyprus Dispute, starting from the 1950s, has always been treated as a "national cause" (milli dava) in Turkey. Almost all political parties on the left and right-wing politics have supported Turkey's active involvement in Cyprus as well as the Cyprus Peace Operation in 1974. Interestingly, the military intervention was made during a coalition government between socialist-leaning CHP (Republican People's Party) and Islamist MSP (National Salvation Party) under the Prime Ministry of Bülent Ecevit. After Turkey's intervention, the island was de facto divided into two

3 The term "Gordian Knot", commonly used to describe a complex or unsolvable problem, can be traced back to the life of Alexander the Great. As the story goes, around 333 B.C., the Macedonian conqueror marched his army into the Phrygian capital of Gordium in modern-day Turkey. Upon arriving in the city, he encountered an ancient wagon, its yoke tied with what one Roman historian later described as "several knots all so tightly entangled that it was impossible to see how they were fastened". Alexander the Great's efforts to cut the Gordian Knot did not turn out to be successful; so, the term has begun to be used for issues that are too difficult to solve. See: Encyclopedia Britannica. 
separate parts with Turkish Cypriots living in the north, under the protection of Turkish Armed Forces, and Greek Cypriots living in the south. In 1983, with Turkey's support, Turkish Cypriots declared the Turkish Republic of Northern Cyprus (TRNC). This country is so far recognized only by Turkey.

After Turkey's intervention and especially after the emergence of TRNC, negotiations for a settlement on the island were initiated under the supervision of the United Nations (UN). These negotiations failed each time. The closest moment for a solution took place in 2004 when UN Secretary-General Kofi Annan prepared a settlement plan (Annan Plan) and convinced all sides for a referendum on the eve of Cyprus Republic's accession to EU (Annan Plan). However, the peace plan, which was supported by Turkey, Greece, the United Kingdom, the EU, and Turkish Cypriots, was rejected by Greek Cypriots. While Turkish Cypriots approved the plan with $65 \%, 76 \%$ of Greek Cypriots rejected the settlement plan (Örmeci 2015: 331). Although negotiations were revitalized and continued after the rejection of the Annan Plan as well, the high momentum for peace of the Annan Plan was never reached once again.

Cyprus has always been important for Turkey for several reasons (Iş1ksal 2015: 297-298). First of all, Cyprus was controlled by the Ottoman Empire between 1571 and 1914 until becoming a British Colony. That is why; there are hundreds of thousands of Turks living on the island, and Turkish language and culture have always been influential in Cyprus. Due to strong ties and kinship between Turks in Turkey and Turks in Cyprus, Turkey's influence on the island is a constant parameter. Secondly, although there are three different guarantor states of the Cyprus Republic since 1960 (namely Turkey, United Kingdom, and Greece), among these countries, the only neighboring country to the island is Turkey. Cyprus is so close to Turkey that Cyprus shores can be seen with the naked eye from Turkish city Mersin in daylight time. Thirdly, Cyprus is a sensitive issue for Turkey, considering Turkish-Greek balance in the Aegean. Since almost all Aegean islands (except Gökçeada-Imvros and Bozcaada-Tenedos) are controlled by Greece, Turkey is very protective of Cyprus. Lastly, due to martyrs given during the Cyprus Peace Operation, as well as Turkish Cypriots who died during the resistance between 1963 and 1974, Cyprus is often described as the "infantland" (yavru vatan) by Turks in Turkey whereas Turkish Cypriots call Turkey often as the "motherland" (anavatan). 
Table 1. Turkey's Cyprus policy in four different periods according to Işıksal

(Iş1ksal 2015: 299-310)

\begin{tabular}{|l|l|}
\hline 1923-1954 & Status Quo and Balance of Power \\
\hline 1954-1974 & Passive Activism \\
\hline 1974-2002 & Active Passivism \\
\hline 2002- & Active Activism \\
\hline
\end{tabular}

If we have to categorize Turkey's Cyprus policy (see Table 1), according to Işıksal, we can briefly talk about four different periods (Işıksal 2015: 299-310). During the first period between 1923 and 1954, which Işıksal calls as "Status Quo and Balance of Power", Turkey was busy establishing a new, modern, and secular nation-state under the leadership of Mustafa Kemal Atatürk and thus, was not able to develop an active foreign policy for protecting Turkish Cypriots. Moreover, during this period, Cyprus was a British Colony, and there was a relative peace between the two communities on the island. During this first period, Turkey was satisfied with the status quo; Atatürk even tried to invite and give land to some Turkish Cypriots who were opposing British colonial rule.

In the second period, which Işıksal calls as "Passive Activism", between 1954 and 1974, Turkey began to support Turkish Cypriots by trying to take the support of the United Kingdom. During this period, Turkey was not ready for an overseas military operation and the United States with the Johnson Letter in 1964 - prevented Turkey's active involvement into the island due to fears of a greater war between Turkey and Soviet Russia which could drag the US and other NATO countries into the war as well. However, during this period, Turkey was able to become a guarantor state of Cyprus Republic in 1960 with London and Zurich Agreements. Turkey's increasing interest in the island during this phase was also in correlation with the rising ethnic tensions on the island.

In the third phase (1974-2002), which Işıksal describes as "Active Passivism", Turkey began to develop active policies towards Cyprus by using its guarantor rights and made a military intervention into Cyprus after the takeover of nationalist Greek Cypriot junta government (EOKA-B) in 1974, aiming to realize Enosis (annexation of Cyprus by Greece). During this phase, Turkey also actively supported Turkish Cypriot leaders in establishing the Turkish Federated State of Cyprus in 1975 and the Turkish 
Republic of Northern Cyprus (TRNC) in 1983. The reason why Işıksal calls this period "Active Passivism" is that, although Turkey saved Turkish Cypriots and helped them to establish states, it continued to defend a two-community and two-zone based federal state.

In the ongoing last phase (2002-), to cut the Gordian Knot, AK Party began to develop bold and active policies towards the island. AK Party first supported the Annan Plan and federal solution in 2004 despite heavy criticism coming from secular nationalist circles and Turkey's security bureaucracy. This gave AK Party and then-Prime Minister Recep Tayyip Erdoğan a chance to get more support from the international community as Ankara was able to prove to the whole world that it was not Turkey that prevents peace and settlement in the island. However, after the rejection of the Annan Plan by Greek Cypriots, Turkey developed more assertive policies towards TRNC to develop political, economic, and cultural ties between Ankara and Nicosia (Lefkoşa). Moreover, during this last phase, with Turkey's help, TRNC's foreign representative offices were being established and multiplied. Nowadays, there are 26 "Missions Abroad" in 19 different countries, according to Deputy Prime Ministry and Ministry of Foreign Affairs of TRNC (Deputy Prime Ministry and Ministry of Foreign Affairs).

\subsection{Different Parameters of the Cyprus Dispute}

Cyprus Dispute is not an ordinary ethnic problem between Turkish Cypriots and Greek Cypriots, but it is rather an international problem that involves many other regional (Turkey, Greece) and international actors (United Kingdom, European Union, United States, Russia). Due to its proximity to the Middle East, the island of Cyprus is often referred to as an "unsinkable aircraft carrier" (AKEL; Milli Gazete 2008) ${ }^{4}$. Moreover, due to recent gas discoveries and energy deals, now also large energy companies contribute to the problem.

According to Bayraklı and Boyraz, Cyprus Dispute has four main parameters; local level (Greek Cypriots and Turkish Cypriots), national level (guarantor states Turkey, Greece, and United Kingdom), international

4 AKEL, Socialist AKEL party in Cyprus uses this term to criticize the US, British, and NATO policies towards the island. See: AKEL. The founder and first President of the Republic of TRNC Rauf Denktaş also used this term to describe Cyprus. See: Milli Gazete (2008). 
level (United States, Russia, and European Union), and global level (United Nations) (Bayraklı and Boyraz 2017: 427). In 2004, although three levels were favourable to the solution, due to the negative Greek Cypriot attitude, local factors prevented the settlement. In recent years, with gas discoveries and deals in the Eastern Mediterranean, a fifth level, consisting of energy politics, was also added to these existing parameters (see Graphic 1).

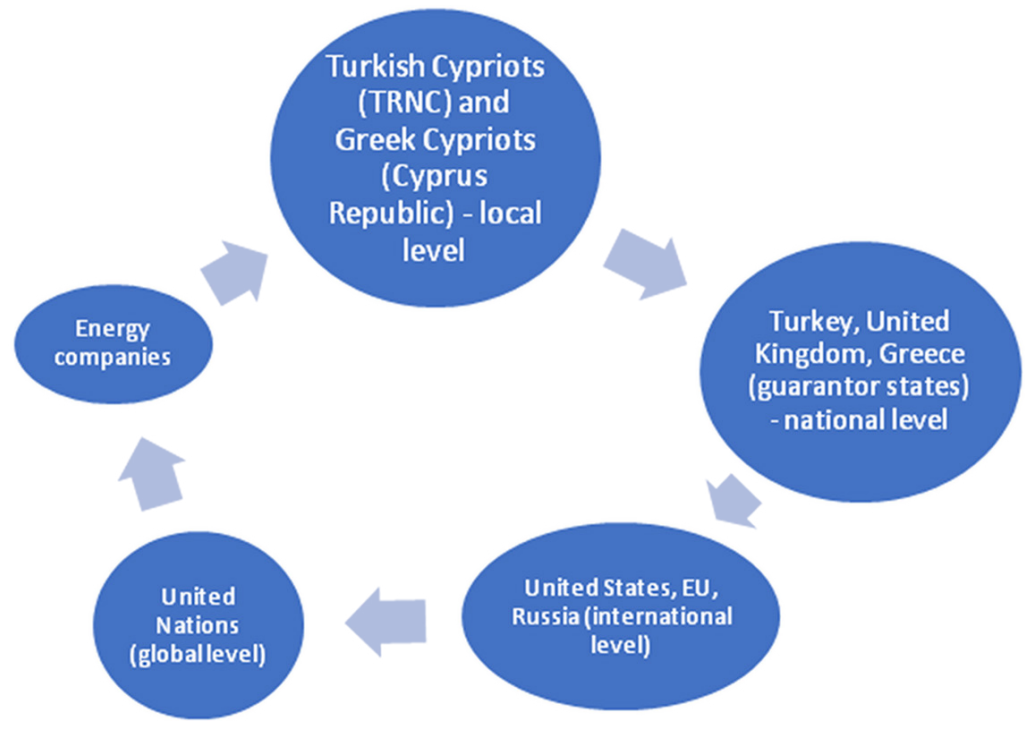

Graphic 1. Different parameters of the Cyprus Dispute

The early 2000s was a test for witnessing the effects of different parameters. At the local level, due to long years of non-recognition and economic problems, the majority of Turkish Cypriots became supporters of the solution for the first time. At the national level, the guarantor states the United Kingdom and Greece did not object to the Annan Plan. With the aim of becoming a full member of the EU, the AK Party government and especially pro-EU business circles (mainly TÜSİAD - Turkish Industry and Business Association) in Turkey also supported the settlement plan (Yaka 2011: 86). At the international level, the United States, Russia, and the EU also did not oppose the plan. At the global level, the UN had already been sponsoring Cyprus Talks and actively supporting peace initiatives for long years (the UN Cyprus Talks). Energy companies and energy politics, on the other hand, were not significant factors in the early 2000s 
since the gas discoveries were just beginning at those years. However, the resistance of Greek Cypriots and EU's policies (not conditioning Cypriot accession to EU with the solution of Cyprus Problem) led to the failure of the Annan Plan. After the failure of the Annan Plan, Peruvian diplomat, and UN Secretary-General Kofi Annan's Special Adviser on Cyprus - Alvaro De Soto, criticized Greek Cypriot attitude and wrote a report advising the lifting of economic sanctions towards TRNC to encourage Greek Cypriots for the solution (AB Haber 2018). Here it should be added that the Greek Cypriot accession to the EU is contradictory with the first article of the Zurich Agreement of February 11, 1959, as well (Appendix 1) ${ }^{5}$.

\subsection{AK Party and Cyprus Dispute}

AK Party is a right-wing (conservative) political party established in 2001 with former young leaders of Islamist Welfare Party (Refah Partisi) such as Recep Tayyip Erdoğan, Abdullah Gül, and Melih Gökçek, etc. The party was established with the hope of reconciling Islam with Western democracy and change Necmettin Erbakan's - leader of the Welfare Party and previous Islamist parties in Turkey - anti-Western and anti-Israel political rhetoric and attitude. AK Party came to a government position in its first election in 2002. Since then, the party was able to govern Turkey and win all elections and referendums in the country. 6 different Turkish Foreign Minister held office in Ankara during AK Party governments. These are; Yaşar Yakış (2002-2003), Abdullah Gül (2003-2007), Ali Babacan (2007-2009), Ahmet Davutoğlu (2009-2014), Mevlüt Çavuşoğlu (2014-2015), Feridun Sinirlioğlu (2015-2015), and Mevlüt Çavuşoğlu again (2015-) (Türkiye Cumhuriyeti Dişişleri Bakanlığı). Although these Foreign Ministers created their nuances in Turkey's Cyprus policy (see Table 3 ), these are also caused by international political developments taking place during their tenure in office. However, it should be noted that, during the AK Party years, especially between 2002 and 2009, pro-settlement

\footnotetext{
5 Appendix 1: Conference on Cyprus: Documents signed and initialed at Lancaster House on 19 February 1959", Article I of the Zurich Agreement is as follows: “The Republic of Cyprus undertakes to ensure the maintenance of its independence, territorial integrity, and security, as well as respect for its Constitution. It undertakes not to participate, in whole or in part, in any political or economic union with any State whatsoever. It accordingly declares prohibited any activity likely to promote, directly or indirectly, either union with any other State or partition of the Island."
} 
rhetoric in Turkey became strongest in the whole Turkish foreign policy history. If we have to set basic principles of Turkish foreign policy towards Cyprus during AK Party governments (2002-), we can come up with these arguments:

- During the rule of AK Party (2002-), Turkey continued to follow former Prime Minister Bülent Ecevit's Cyprus policy. Ecevit, on July 20, 1974 - few minutes before Cyprus Peace Operation had started - said that the operation would have a great contribution to mankind and peace and that they aim to bring peace to the island not only for Turks but also for Greeks (Ecevit Kıbrıs Barış Harekatını). So, similar to Ecevit, AK Party leaders and Turkish Foreign Ministers never opposed officially to a federal solution in Cyprus. However, especially before the elections, more nationalist rhetoric was used in local rallies to attract nationalist votes. However, after the failure of the 2017 Crans-Montana peace negotiations, Turkish leaders' nationalist rhetoric increased considerably.

- The fundamental reason of AK Party's pro-settlement or pro-solution policy towards Cyprus was its earlier domestic political clash with Turkish Armed Forces, an army known for its harsh pro-secular approach and heavy involvement into politics as it is proven with three major military coups (27 May 1960, 12 March 1971, and 12 September 1980) and various coup attempts in Turkish political history. AK Party, on the other hand, has always defended civilian supremacy and depoliticization of the security administration. The second most important reason was the AK Party's aim to make Turkey a full member of the EU. However, as Turkey's EU membership hopes decreased, the AK Party government's desire to solve the Gordian Knot in Cyprus also fell.

- Although AK Party did not use nationalist rhetoric and did not implement openly nationalist policies towards Cyprus, during the rule of AK Party (2002-), Turkey's economic weight and influence on Cyprus constantly increased. That is why; Bozkurt claimed that Turkey has become the IMF of Northern Cyprus rather than the motherland during AK Party governments (Bozkurt 2014: 83). For instance, Turkey initiated an important infrastructural project called "Northern Cyprus Water Supply Project" or "Peace Water" (Barış Suyu) (see Map 1) to solve water shortage in Northern Cyprus (Devlet Su İşleri Genel Müdürlüğü). Moreover, Turkey-TRNC bilateral trade reached 
almost 2 billion US dollar as of 2018 (see Table 2), which obviously helps Turkey to have more effect over TRNC due to its dominant position in bilateral trade (Türkiye Cumhuriyeti Ticaret Bakanlığı).

\section{KKTC SU TEMIN PROJESI}

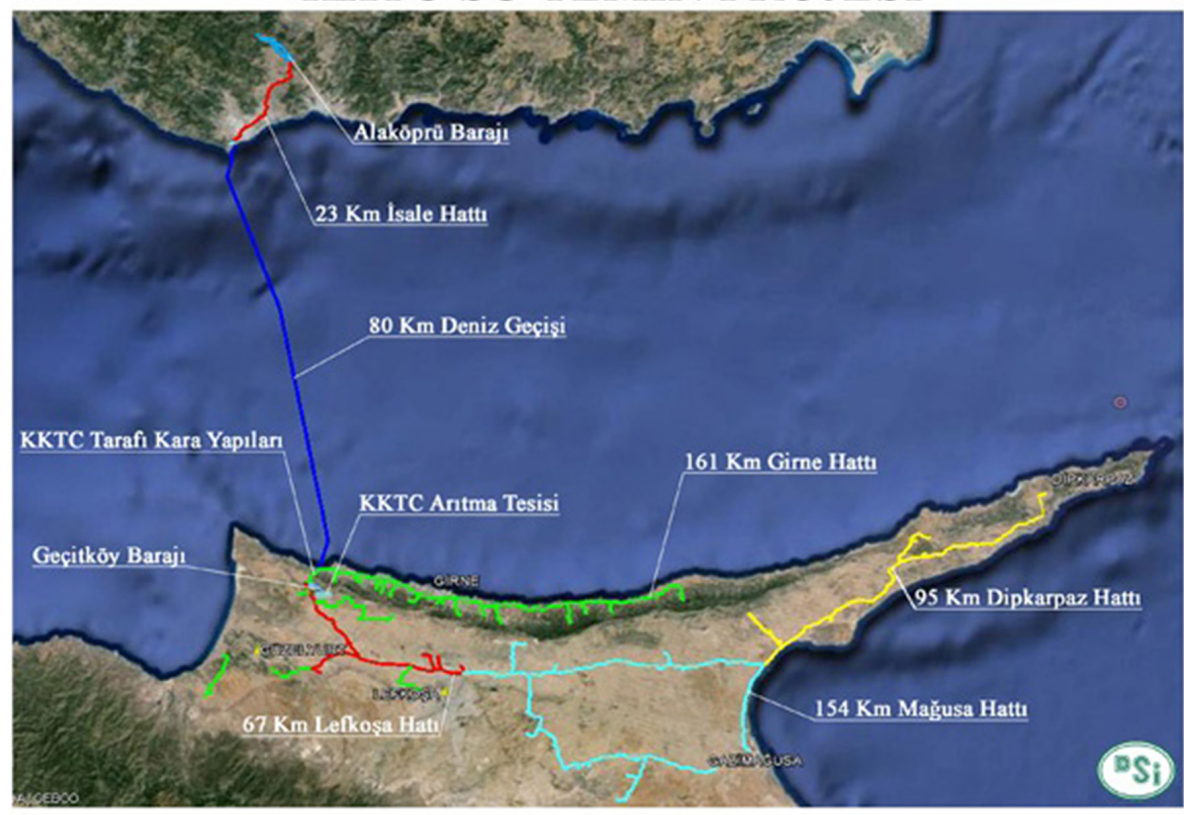

Map 1. "Peace Water" Project

Table 2. TRNC's trade statistics (1,000 US dollar)

(Türkiye Cumhuriyeti Ticaret Bakanlığı)

\begin{tabular}{|l|r|r|r|r|r|}
\hline & \multicolumn{1}{|c|}{$\mathbf{2 0 1 4}$} & \multicolumn{1}{c|}{$\mathbf{2 0 1 5}$} & \multicolumn{1}{c|}{$\mathbf{2 0 1 6}$} & \multicolumn{1}{c|}{$\mathbf{2 0 1 7}$} & \multicolumn{1}{c|}{$\mathbf{2 0 1 8}$} \\
\hline Imports & $1,784,268$ & $1,500,577$ & $1,557,190$ & $1,778,404$ & $1,816,364$ \\
\hline Exports & 133,985 & 118,078 & 105,487 & 105,616 & 100,852 \\
\hline Trade Balance & $-1,650,283$ & $-1,382,498$ & $-1,451,702$ & $-1,672,834$ & $-1,715,512$ \\
\hline Total Volume & $1,918,253$ & $1,618,655$ & $1,662,677$ & $1,884,020$ & $1,917,216$ \\
\hline
\end{tabular}


- Turkish foreign policy towards Cyprus is aimed not only at protecting Turkish Cypriots but also increasing Turkey's economic interests in the island as well as increasing Turkey's influence in the Eastern Mediterranean.

Table 3. Turkey's Cyprus policy during AK Party era

\begin{tabular}{|l|l|}
\hline 2002-2004 & Proactive Policy Favoring Solution for EU Membership \\
\hline 2004-2009 & 'Strategic Gain' Argument and Tactical Moves \\
\hline 2009-2015 & Remembrance of Cyprus as Part of Security Politics \\
\hline 2015-2017 & Last Effort for Solution \\
\hline 2017- & Increasing Nationalism \\
\hline
\end{tabular}

\subsubsection{2-2004: Proactive Policy Favoring Solution for EU Membership}

In this first period during which Yaşar Yakış and Abdullah Gül held office as Turkey's Foreign Affairs Ministers, AK Party government showed a determined and solid stance for the solution of Cyprus Dispute. The main motive of the government was to take more international support against the danger of a secular nationalist military coup or a military intervention, as in the case of February 28, 1997 process. In that sense, the EU was seen by the government as a savior against the Turkish Armed Forces. Yaşar Nuri Öztürk referred to this behavior as taking shelter in the mediation of the EU rather than the malignity of Ankara (Öztürk 2005). Turkey's then-Foreign Affairs Minister Yaşar Yakış even said that Turkish Armed Forces will be in the position of invader if there would not be a solution in Cyprus (Hürriyet 2002).

According to Bayraklı and Boyraz, during this first phase, AK Party leaders sincerely believed that Turkey could become an EU member and they saw pro-settlement rhetoric and policy in Cyprus as a way to break down prejudices against Ankara in Brussels as well as a security fence against the danger of a secular military coup against themselves (Bayraklı and Boyraz 2017: 429). In that sense, the AK Party used the EU membership process as leverage to overcome military influence. It is not surprising that, in the 2002 election manifesto of AK Party (herşey Türkiye için!), "Belgium model" was mentioned concerning Cyprus Dispute (AK Parti 2002), and ultranationalist MHP (Nationalist Action Party) and its leader Devlet Bahçeli was the harshest critic of the government (MHP 
AR-GE Merkezi 2003). AK Party's pro-settlement policy in Cyprus during this first phase was not just a tactical move; the party was so insistent on the solution that the government even afforded the risk of confronting TRNC's founder and first President of the Republic Rauf Denktaş, often seen as a national hero in Turkey and TRNC. Denktaş also claimed that the AK Party government exerted pressure on him to change his views to defending the status quo on the island (Şimşir 2004: 245). During this period, liberals and pro-EU circles, as well as TÜSİAD, actively supported the AK Party government's sincere efforts to solve the Cyprus problem to make Turkey a full member of the EU by solving the Gordian Knot in Cyprus.

\subsubsection{4-2009: 'Strategic Gain' Argument and Tactical Moves}

Although the AK Party government took high risks by supporting the Annan Plan, and Turkish Cypriots also approved the plan, upon the rejection of settlement plan by Greek Cypriots, the EU accepted Greek Cypriot administration an EU member as the representative of the whole island by 2005 . This decision decreased full membership hopes in Turkey and harmed the EU's prestige in Turkey. Moreover, the AK Party government was blamed by secular nationalists for treason due to its Cyprus policy favoring solution. AK Party was also subjected to heavy criticism, and huge demonstrations (Republican rallies) took place due to an emerging political crisis concerning the Presidential election in 2007. Thus, AK Party officials began to present their positive stance for Annan Plan with the 'strategic gain' argument by pointing out international support (only at rhetorical level) given to Turkey and Turkish Cypriots.

As economic sanctions against TRNC continued despite some promises given by EU leaders ${ }^{6}$, reactions against the EU increased both in Turkey and among Turkish Cypriots (DW Türkçe 2004). Continuation of economic sanctions against TRNC also helped Turkey to increase its economic effect over Northern Cyprus. However, during this period, TRNC - with Turkey's active support - lifted all barriers for border-crossing of Cyprus citizens to increase social integration between Turkish and Greek Cypriots, although Greek Cypriot administration was reluctant (Türkiye Cumhuriyet Dişişleri Bakanlığı). Moreover, negotiations between Ankara

6 For instance, then-EU commissioner for enlargement Günter Verheugen said that Northern Cyprus should be saved from economic isolation. See: DW Türkçe 2004. 
and Brussels started officially on October 3, 2005; but Ankara's refusal to open its airports and harbors to Greek Cypriot aircraft and ships led to the freezing of 8 chapters (among a total of 35 chapters) in December 2006 (Işıksal 2016: 268).

AK Party's "strategic gain" argument during this phase was not non-sense since - after Turkey's pro-settlement stance during the Annan Plan - the number of TRNC's foreign representative offices (Missions Abroad) increased, Turkish Cypriots gained new rights such as being able to pass to the other side and getting the Cyprus Republic and thus, EU identities ${ }^{7}$, and Turkish Cypriot leaders - with Turkey's help - participated in some international organizations (Hürriyet 2018). For instance, then-President of the Republic of TRNC Mehmet Ali Talat gave the trophy after the Formula 1 race organized in Istanbul (Haberler.com 2006) ${ }^{8}$. However, even during this period, which Işıssal defines as "Active Activism", Ankara, in fact, continued to support UN-sponsored peace talks and began to use soft power methods (economic power and cultural influence) rather than military power in Cyprus. Thus, in 2008, Turkey openly supported negotiations initiated by Mehmet Ali Talat ve Greek Cypriot leader Dimitris Christofias.

\subsubsection{9-2015: Remembrance of Cyprus as Part of Security Politics}

2009-2015 period witnessed the remembrance of Cyprus as part of security politics due to development taking place in the Middle East. During this third phase, Turkey's hopes for EU membership further decreased, and as a reaction to the Greek Cypriot administration's blockage of 6 chapters in Turkish-EU negotiations, Ankara decided to prevent the joining of Cyprus Republic into NATO meetings (Bayraklı and Boyraz 2017: 438). Moreover, Talat-Christofias talks failed despite high hopes pumped by the international press and general agreement between two leaders on many issues (Talat 2012).

These developments coincided with the emergence of a revolutionary process in the Middle East and North Africa in 2011, the Arab Spring, which caused large scale migration movements as well as security risks. Although

7 Nowadays, 110,000 Turkish Cypriots have EU passports thanks to their Cyprus Republic identity. See: Hürriyet 2018.

8 However, IMSA-International Motor Sports Association gave Turkey a 5 million US dollar fine due to this behavior. See: Haberler.com 2006. 
Arab Spring aimed at spreading democratic values, terrorist groups such as Al Qaeda, ISIS, and PKK also took advantage during this process, and especially the ongoing civil war in Syria created huge risks for neighboring countries. Thus, Cyprus, traditionally known as an "unsinkable aircraft carrier", became an important place for many countries, including Turkey and the United Kingdom, because of its proximity to the Middle East (Erlanger and Castle 2015) ${ }^{9}$. During this period, Turkey followed an active foreign policy for toppling down the Bashar al Assad regime in Syria and became the target of many terrorist organizations, including ISIS, Al Qaeda, PKK/ PYD/YPG as well as the Syrian State. Thus, Turkish leaders began to give more nationalist messages about Cyprus to use Turkey's military presence there as an outpost zone in its fight against terrorism and the Assad regime. For instance, before the general election in 2011, in AK Party's electoral manifesto, concerning Cyprus, this phrase was used: Turkey will continue to support TRNC's international prestige and activities to provide safety and welfare of Turkish Cypriots (Haber7.com 2011).

This more nationalist stance was also supported by Greek Cypriot administration's talks and agreements with other countries about maritime jurisdiction zones and natural gas drilling activities in the Eastern Mediterranean with some major energy companies without Turkey's or Turkish Cypriots' approval. Besides, the replacement of Mehmet Ali Talat with Derviş Eroğlu, a more nationalist political leader following Denktaş's footsteps, in 2010, was also an influential factor during this process.

\subsubsection{5-2017: Last Effort for the Solution}

After the unexpected victory of pro-settlement socialist veteran politician Mustafa Akıncı in TRNC in 2015, Turkish Cypriots urged Ankara for another negotiation process. Akinc1 was hopeful since the leader of Greek Cypriots Nicos Anastasiades was also a pro-settlement politician who gave "yes" vote and personal political support to Annan Plan in 2004. UN Cyprus Talks resumed in May 2015, and positive messages were given by two leaders. However, due to disagreements about the presence of Turkish soldiers and the guarantee system, talks failed once again in 2017

9 For instance, the British Akrotiri airbase station was used in Operation Shader in 2014, against ISIS elements in Syria. In 2015 also, the Akrotiri base was used in operations against ISIS. See; Steven Erlanger \& Stephen Castle (2015), “British Jets Hit ISIS in Syria After Parliament Authorizes Airstrikes", The New York Times. 
in Crans-Montana (BBC Türkçe 2017). In addition to reciprocal mistrust between Turkey and Greek Cypriot administration, the transformation of Turkish-EU relations into a political interest matter with the 2016 Syrian refugees agreement (often seen as Ahmet Davutoğlu-Alexis Tsipras deal) rather than full membership process, also decreased Ankara's hopes and willingness for a solution (BBC Türkçe 2016).

\subsubsection{7-: Increasing Nationalism}

The failure of Crans-Montana talks, as well as increasing problems between Turkey and the EU, led to increasing nationalism in the AK Party's Cyprus policy as well as in TRNC. For instance, TRNC Foreign Affairs Minister Kudret Özersay, in his talk at Chatham House in 2018, stated that they should focus on the reasons for the failure of negotiations rather than renegotiating (KKTC Enformasyon Dairesi 2018). Turkish Minister of Foreign Affairs Mevlüt Çavuşoğlu also stated in 2019 that Greek Cypriot administration does not want to share the governmental power and wealth with Turkish Cypriots (KKTC Enformasyon Dairesi 2019). Also, upon Greek Cypriot administration's maritime zone and energy agreements (EastMed Pipeline Project) with Israel and Greece (IGI Poseidon), Turkey signed a similar agreement with Libya in December 2019 to prevent this project and defend its maritime and economic exclusive zone (Alarçin 2020). President Erdoğan, on the other hand, made it clear that Turkey will never allow the usurpation of Turkish Cypriots' rights over Cypriot gas resources and increased the dose of nationalism constantly after 2017 (Hürriyet 2019). During this process, Turkish ships even blockaded Italian ENI Company's drilling ship in the Mediterranean (Reuters 2018). Here, it should also be added that, as a domestic political factor, President Erdoğan and his party keeps the majority in the parliament and large electoral support thanks to its electoral coalition (People's Alliance - Cumhur Ittifakı) with the nationalist MHP and thus, could not afford to change his nationalist-leaning Cyprus policy. Besides, as an international factor, it should be underlined that, after the Brexit process, now two out of three guarantor countries of Cyprus Republic are non-EU member states (Turkey and United Kingdom), which shows that Nicosia's membership into EU will be more questionable in the new term and Turkey's increasing nationalism policy will find a more comfortable ground. Moreover, the replacement of left-wing Alexis Tsipras (who became the first Greek PM to directly meet with Turkish Cypriots in 2015 (T24 2015), and gave more balanced messages about 
Cyprus Dispute) with right-wing and nationalist Kyriakos Mitsotakis as Greek Prime Minister also will further strengthen this trend and Cyprus Dispute and the disagreement in the Eastern Mediterranean will be the source of new tensions in the coming years.

\section{Developments in terms of Energy Politics in the Eastern Mediterranean and Their Effects on Cyprus Dispute}

\subsection{New Gas Discoveries in the Eastern Mediterranean}

Energy exploration studies that have been done in the Eastern Mediterranean since 2008 have resulted in the discovery of important oil and natural gas reserves. Thanks to these discoveries, the Eastern Mediterranean has turned out to be a potentially important energy transfer center. At the same time, when the Eastern Mediterranean's geographical position as being a door to the Middle East is taken into consideration, the discovery of energy resources has direct effects over global geopolitics. Due to these discoveries, the high potential of reserve volumes, and the interests of energy firms in this region, the Eastern Mediterranean has become a focal point of hot conflicts in today's world. On the other hand, Eastern Mediterranean countries have been struggling with political questions, border conflicts, and domestic turmoil. The occurrence of those conflicts within regional, national, and international dimensions should not be seen as a coincidental situation. The most significant conflicts within the Eastern Mediterranean are the chaotic political situations in Egypt, Libya, and Syria caused by the eruption of Arab Revolts (Arab Spring) since 2010, as well as the protracted Palestine and Cyprus conflicts. When it comes to the energy dimension in the Eastern Mediterranean, according to the "Fact Sheet 2010-3014" (S. Department of the Interior / U.S. Geological Survey 2010/a), a document of the U.S. Geological Research Institution, 1.7 billion barrels of technically recoverable oil reserves and 3.5 trillion cubic meters $(\mathrm{tcm})$ of technically recoverable natural gas reserves exist in the Levantine East Basin. In parallel with this, according to "Fact Sheet 2010-3027" (U.S. Department of the Interior / U.S. Geological Survey 2010/b), a document of the same institution, the presence of 1.8 billion barrels of technically recoverable oil resources and $6.3 \mathrm{tcm}$ of 
technically recoverable natural gas resources were declared in this area (Kisacik 2019a).

Table 4. Eastern Mediterranean Gas Discoveries (Kıstak 2019b)

\begin{tabular}{|l|c|}
\hline \multicolumn{1}{|c|}{$\begin{array}{c}\text { Eastern Mediterranean } \\
\text { Gas Field }\end{array}$} & $\begin{array}{c}\text { Gross Mean Resources } \\
\text { (bn cubic meters) }\end{array}$ \\
\hline Aphrodite & 140 \\
\hline Zohr & 850 \\
\hline Leviathan & 620 \\
\hline Tamar & 280 \\
\hline Other (est.) & 450 \\
\hline Total & 2,340 \\
\hline
\end{tabular}

Following these estimations, coastal states in this region have been intensifying their efforts to discover oil and natural gas resources in their offshore fields. Among them, especially in terms of natural gas, the discoveries of Israel, Greek Cypriot administration (Cyprus Republic), and Egypt have been the most significant ones within the context of Eastern Mediterranean energy geopolitics. When we analyze Israel's total natural gas reserves (see Table 4), its most significant reserves are located in Tamar and Leviathan fields in the offshore of this country, totaling as 900 billion cubic meters (bcm) and discovered by the American company Noble Energy. The Israeli government has decided to export just $40 \%$ of these reserves, and the rest of these resources are considered to be allocated for meeting the country's energy demand. In this manner, another important natural gas reserves are positioned in Cyprus. In Cyprus, the Aphrodite natural gas field (see Table 4) totaling $140 \mathrm{bcm}$ has come into the agenda. Nicosia has been considering benefiting from this volume of natural gas both in terms of domestic use and exportation. Both Israel and Cyprus' natural gas reserves have been discovered by foreign energy companies within the end of the first decade of the 2000s. Lastly, for Egypt, in 2015, Italian energy company ENI has discovered an $850 \mathrm{bcm}$ natural gas reserve in the Zohr field (see Table 4). Since then, these three countries have been intensively searching for monetizing their gas resources via several alternatives, namely pipelines and LNG plants. In this manner, it should be pointed out that Lebanon also has the potential of more than $700 \mathrm{bcm}$ of natural gas in this region. But this country has been in a struggle over some 
of its Exclusive Economic Zones (EEZ) with Israel (see Map 4). Moreover, in terms of Cyprus, there have been serious disagreements between Greek Cypriot administration and Turkey over the determination of EEZs around the island of Cyprus (see Map 3 and Map 4) (Kisacik (2019a).

\subsection{Turkey's Response}

Greek Cypriot administration has made several efforts toward the declaration of its own EEZs in order to benefit more from the Eastern Mediterranean (Kesgin 2018) ${ }^{10}$ basin in the 2000s. Within this context, Nicosia has made efforts on the discovery of hydrocarbons in its self-declared fields that are supported by such regional and external actors as France, Italy, the U.S., and the EU. In parallel with this, the Greek Cypriot administration has made several discovery initiatives through the signing of EEZ (Maritime Boundary Office) ${ }^{11}$ agreements with the regional countries in the past years. However, the pursuit of an independent EEZ policy by Greek Cypriot administration in the Eastern Mediterranean, the rapprochement taking place between the trio of Cyprus-Israel-Greece, and the political support presented by the EU and France to Greek Cypriot administration are considered challenges to Turkey's security policies and national interests within this region by Ankara.

The Greek Cypriot administration, aiming to benefit actively from the hydrocarbons within the region, has increased its territorial waters to 12 nautical miles. Within this context, first of all, the Greek Cypriot administration, by taking advantage of the status of "Sovereign Cyprus Republic", has declared its EEZ. After this, Nicosia has tried to legitimize

10 For a comprehensive study on Eastern Mediterranean Security from Global and Regional Perspectives, please see: Kesgin 2018.

11 "States that are parties to UNCLOS are obliged to reach an agreement by negotiation on permanent maritime boundaries with their neighbours where they have competing claims to Exclusive Economic Zones or continental shelf rights. UNCLOS sets out the principles for delimitation of the continental shelf and the Exclusive Economic Zones between States with opposite or adjacent coasts, namely, that they must reach an agreement based on international law, to achieve an "equitable solution". It was left to international courts and tribunals to determine what this meant. Dispute settlement bodies, notably the International Court of Justice and the International Tribunal for the Law of the Sea have since interpreted and applied the relevant provisions of UNCLOS, and developed a clear methodology for delimiting boundaries between two States". Maritime Boundary Office. 
its activities through the opening of those fields to international energy companies. However, it should be kept in mind that it is hard to define the EEZs of territorial waters in problematic regions such as Cyprus. To benefit maximum from the East-Med, the Greek Cypriot administration has made EEZ agreements with Egypt in 2003 (Agreement between the Republic of Cyprus and the Arab Republic of Egypt), Lebanon in 2007 (Sezer), ${ }^{12}$, and Israel in 2010 (Agreement between the Government of the State of Israel and the Government of the Republic of Cyprus) ${ }^{13}$ following the "Median Line Principle" (A letter dated 20 June 2011 from the Minister for Foreign Affairs; Ak 2014: 59-69) ${ }^{14}$.

Due to these agreements, a conflictual situation with Turkey's territorial waters and the continental shelf has been created (see Map II) by the Greek Cypriot administration. Within the context of this situation, the Greek Cypriot administration has made licensing activities toward the exploration of hydrocarbons. For this, American Noble Energy in the $12^{\text {th }}$ parcel, Italian ENI in the $2^{\text {nd }}, 3^{\text {rd }}$, and $9^{\text {th }}$ parcels, and French TOTAL in the $10^{\text {th }}$ and $11^{\text {th }}$ parcels were licensed by the Greek Cypriot administration. However, these authorizations were severely criticized by Ankara (Örmeci and Kısacık 2019: 71). In response to this, Turkey and TRNC signed an EEZ agreement in September 2011 (Erciyes 2012) ${ }^{15}$. It has to be emphasized within this context that, apart from other Mediterranean states, Turkey is not one of the signatory states of the 1982 UN Convention on the Law of Seas. For this reason, it is not a party to this convention. Both Turkey and TRNC have been underscoring that without the existence of a multilaterally agreed EEZ agreement between the coastal states in the Eastern Mediterranean, as well as the resolution of the Cyprus Dispute, the unilateral initiatives of the Greek Cypriot administration within the

12 For a detailed analysis of this issue, please see: Sezer.

13 "Agreement between the Government of the State of Israel and the Government of the Republic of Cyprus on the Delimitation of the Exclusive Economic Zone, signed in Nicosia on 17 December 2010 (entry into force: 25 February 2011; registration \#:I-48387.

14 For the reaction of Lebanon on the signing of EEZ Agreement between the Greek Cypriot administration and Israel, please see, "A letter dated 20 June 2011 from the Minister for Foreign Affairs and Emigrants of Lebanon addressed to the Secretary-General of the United Nations concerning the Agreement between the Government of the State of Israel and the Government of the Republic of Cyprus on the Delimitation of the Exclusive Economic Zone, signed in Nicosia on 17 December 2010". Also see: Gökhan Ak 2014.

15 For a detailed analysis of this issue, please see: Erciyes 2012. 
context of delimitation of EEZ and licensing the international energy companies on the exploration of hydrocarbons are illegitimate and risky.

OVERLAPPING CLAIMS TO GAS-RICH CYPRIOT WATERS

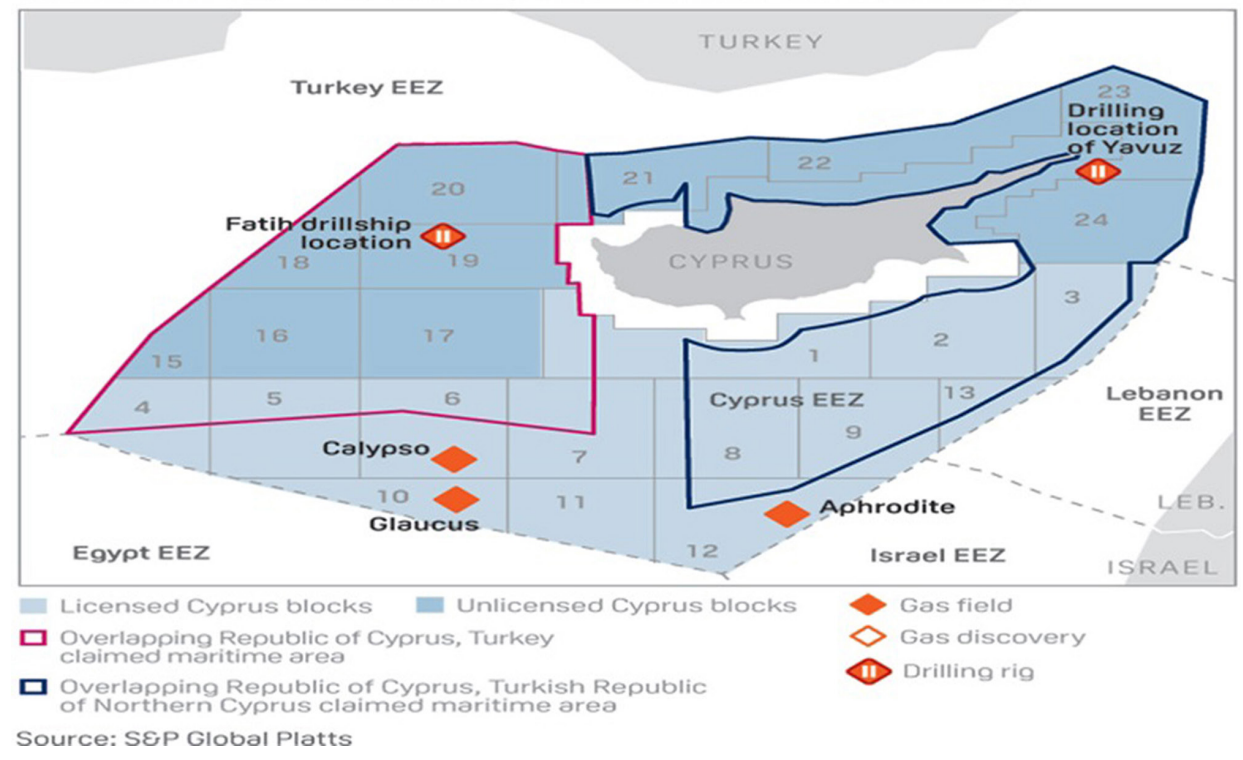

Map 2. Overlapping claims to gas-rich Cypriot waters (Elliott 2019)

In parallel with these developments, a critically important initiative was set forth by Turkey and Libya on November 27, 2019. On this date, the Turkish government and the Libyan government officially recognized by the United Nations-led by Fayez al-Sarraj- have signed a Memorandum of Understanding $(\mathrm{MoU})$ regarding the determination of EEZs between them (see Map 3 and Map 4) (Kisacik 2020). The agreement is named as "Restriction of Marine Jurisdictions", anticipated for the expansion of security and military collaboration between Turkey and Libya (TRT World 2019). Turkish Foreign Ministry spokesman Hami Aksoy has evaluated this agreement as:

The agreement was following the court decisions that create the international jurisprudence and international law, including the relevant articles of the United Nations Convention on the Law of the Sea. Turkey has the longest continental coastline in the Eastern Mediterranean. The islands, which lie on the opposite side of the median line between two mainlands, cannot create maritime jurisdiction areas beyond their 
territorial waters and that the length and direction of the coasts should be taken into account in delineating maritime jurisdiction areas... (Zontur 2019).

\section{Turkey's maritime boundaries in E. Mediterranean}

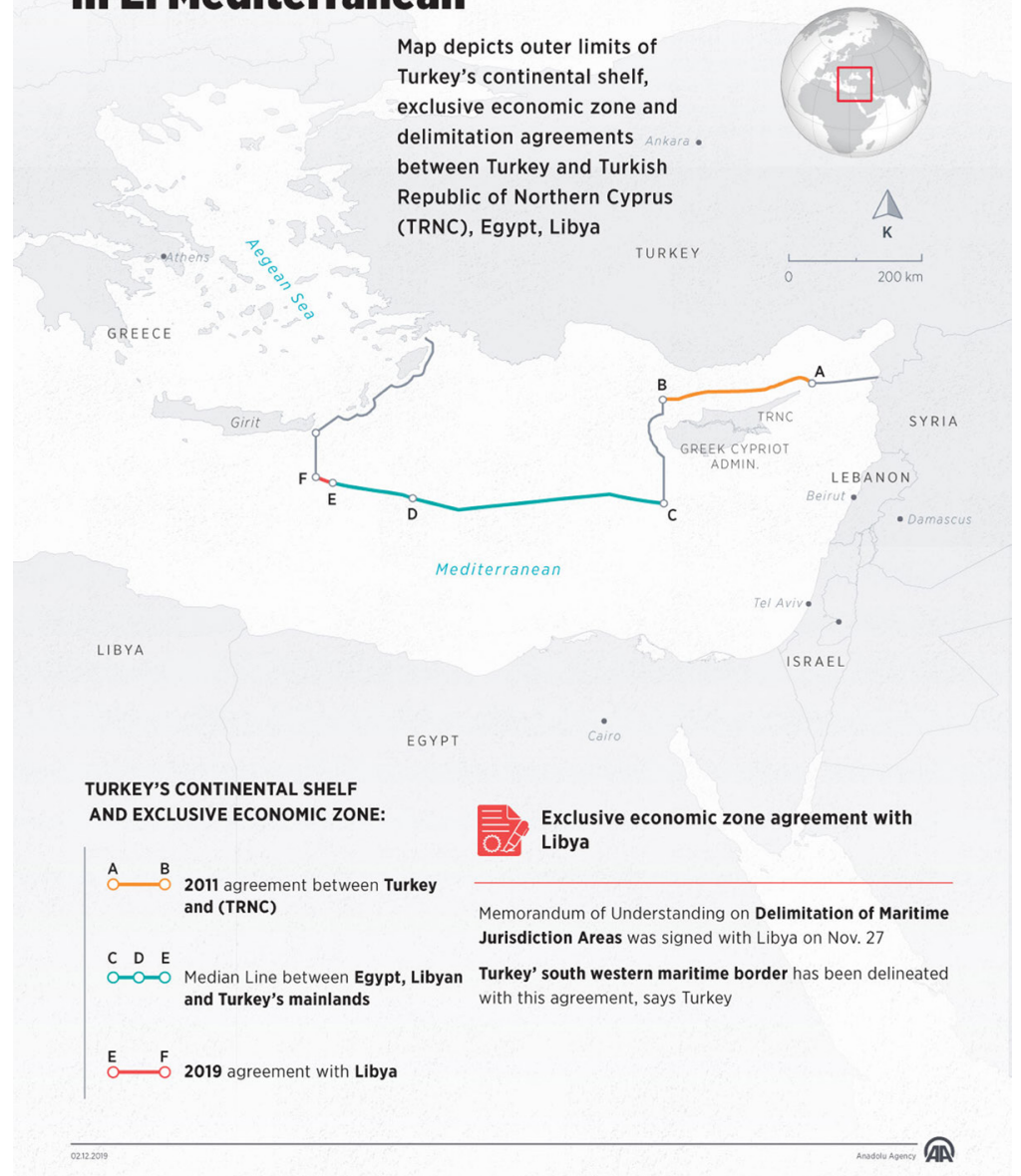

Map 3. Turkey's maritime boundaries in East Mediterranean (Zontur 2019)

On January 29, 2019, this agreement was strongly criticized by the Foreign Ministers of Italy and Greek Cypriot administration as "unacceptab$\mathrm{le}^{\prime \prime}$, and as a violation of international laws ignoring the sovereign rights of other countries. Italian Foreign Minister Luigi Di Maio and his Cypriot 
counterpart Nikos Christodoulides also underscored in a joint declaration after meetings in Rome that the deal cannot have any legal impact on other countries (Ekathimerini 2020). Turkish Foreign Ministry spokesman Hami Aksoy on the other hand, on January 30, 2020, criticized Rome's unfortunate explanations regarding the maritime deal between Turkey and Libya. Aksoy also stressed that Turkey invites all EU members to change their manners that ignore and underestimate the rights of Turkish Cypriots. Moreover, Aksoy underlined that, as co-existing communities, Turkish Cypriots have equal rights with Greek Cypriots concerning oil and natural gas resources around the island. In this manner, Hami Aksoy also recalled the granting of exploration and drilling licenses to Turkish Petroleum Corporation (TPAO) by TRNC in 2011. In parallel with these licenses, the current research and drilling activities of the TPAO target to safeguard the rights of Turkish Cypriots, not Turkey. Aksoy also highlighted that the TPAO's initiatives would not be ended until these rights are assured via mutual termination of all "off-shore" activities, or when collaboration will be attained between the TRNC and the Greek Cypriot administration. Furthermore, Aksoy mentioned that Ankara discards criticism against its MoU with Tripoli, recalling the fact that EU countries, including Italy, remained silent about the similar deal between the Greek Cypriot administration and Egypt in 2003. Lastly, it was stressed by Aksoy that Turkey would continue safeguarding the rights of Turkey as well as Turkish Cypriots within the Eastern Mediterranean (Hamit 2020; Republic of Turkey Ministry of Foreign Affairs 2020).

\subsection{Alternative Projects for Eastern Mediterranean Gas Resources}

When it is considered from the monetization of natural gas reserves found in the Eastern Mediterranean, three options (see Map 5) have widely been discussed among the related states and energy companies.

A) East-Med Pipeline: The first option is the East-Med Pipeline (see Map V) envisaged transporting the Israeli reserves over Greek Cypriot administration to European markets with 10 billion cubic metres (bcm) of gas per annum. This project is included in the list of "EU List of Projects of Common Interest" (European Commission 2019; European Commission (2019b). As of January 2, 2020, an agreement for constructing a pipeline was signed by the governments of Greece, Israel, and Cyprus that might provide Europe with $4 \%$ its yearly natural gas requirements as of the 
middle of the decade. The deal stays a declaration of political determination. Nevertheless, it remains nowadays dependent on the construction consortium, under the leadership of the Public Gas Corporation of Greece (DEPA) and Italy's Edison, to provide the approximately six billion euros (\$6.7bn), which are the projected cost of the pipeline. East Med will be laying just about 1,900 kilometers (1,181 miles) from Israeli and Cypriot natural gas fields in the eastern Mediterranean to Italy by Greece. The three signatory states of the East-Med Pipeline have been underscoring that the realization of this pipeline is going to be a "win-win" situation for all the related parties, and it is not developed against other countries, primarily Turkey (Psaropoulos 2020). This trilateral agreement signed among Tel-Aviv (Jerusalem)-Nicosia-Athens on the construction of East-Med Pipeline has been warmly evaluated by the EU spokesperson on January 2, 2020, as:

The agreement is a welcome development. The pipeline should be seen as one option of tapping EastMed gas supplies for the EU alongside shipping it to the EU by tankers in the form of LNG. It's important to explore further the costs and benefits of both main options. In this context, the EastMed pipeline is one option to bring that gas to the continent (Michalopoulos 2020).

Here, it should be outlined in detail how this trilateral agreement is assessed by the Republic of Turkey. The Spokesperson of Republic of Turkey Ministry of Foreign Affairs Ambassador Hami Aksoy has evaluated this issue as:

Any project disregarding Turkey, which has the longest coastline in the Eastern Mediterranean, and the Turkish Cypriots, who have equal rights over the natural resources of the island of Cyprus, cannot succeed. Turkey is the most commercially feasible and secure route for the utilization of the natural resources in the Eastern Mediterranean and their transfer to consumer markets in Europe, including Turkey... (Bayar 2020).

Two expert views on the East-Med Pipeline would be quoted to better comprehend the project's significance for regional energy security. One of them is from Prof. Oktay Tanrisever, an expert on energy diplomacy and the International Relations Department chair of the Middle East Technical University. Some of his significant assessments on this issue are:

The project cannot be realized also because of legal difficulties as the planned pipeline would pass through the Turkish Exclusive Economic Zone. Isolation of Turkey does 
not benefit anyone, and it is not sustainable in the long run. The parties will eventually consider revising the pipeline project by cooperating with Turkey for the construction of a mutually beneficial pipeline project, with a route from the island of Cyprus passing through Turkey. Turkey has been offering its willingness to cooperate with all the countries concerned... (Mehmet 2020).

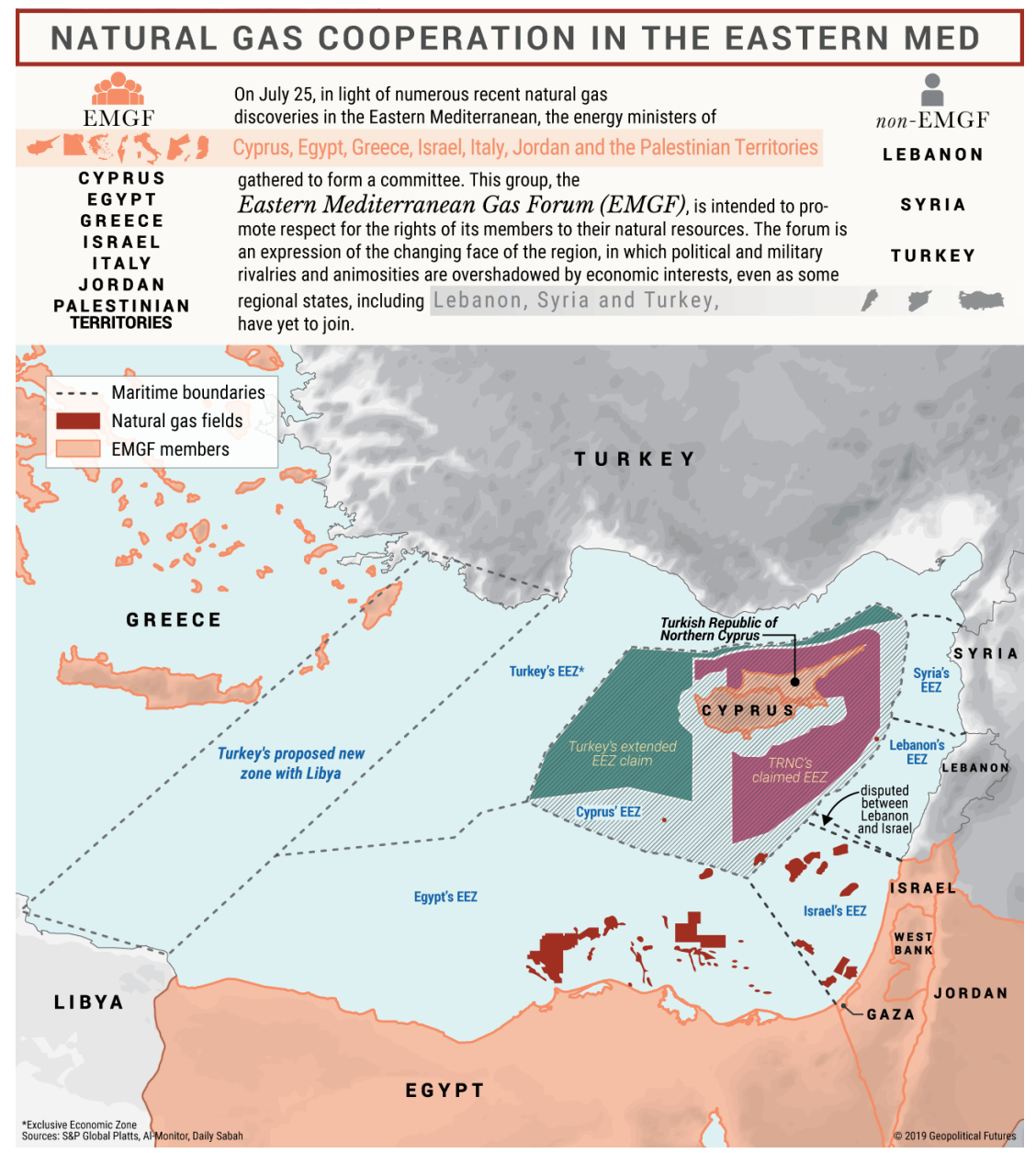

Map 4. Natural Gas Cooperation in the Eastern Mediterranean (Rose 2020)

An important problem within the context of the implementation of the project stands in its expensiveness and the required volume, for covering the costs has not hitherto really been provided. For the Greek daily 
newspaper To Vima, it is estimated that the transference charge of the natural gas is going to be three times less expensive if the pipeline goes over Turkey, rather than the route proposed by the EastMed. In line with this projection, Androulla Vassiliou, former Greek Cypriot EU Commissioner for Health and also for Education, Culture, Multilingualism \& Youth, has evaluated this pipeline as for a pipeline that will be so expensive that it will be impossible to finance, for natural gas the price of which we do not know if we can justify the expenditure and the quantities of which are still unknown. It is all a game of impressions (Mehmet 2020). In line with these assessments, Turkish official approach toward the latest energy-related developments in the Eastern Mediterranean has best been put forward by President Erdoğan on January 8, 2020, as follows:

The sole purpose of our hydrocarbon exploration efforts in the Eastern Mediterranean is to protect the interests of our country and the TRNC. As we always say, no project which excludes Turkey in the Eastern Mediterranean has a chance to be put into effect economically, legally and diplomatically [...] (Presidency of the Republic of Turkey 2020).

B) LNG: The second option for the transportation of East-Mediterranean natural gas primarily to the European markets is the LNG. In this option, the construction of an LNG plant in Vasilikos is considered (see Map V). It is planned to transport not only the Greek Cypriot administration's gas but also the Israeli resources. But this option is very hard to realize because of insufficient natural reserves of Greek Cypriot administration and Israel's insistence on the construction of this plant on its territory due to national security reasons. Moreover, one also should mention that Tel-Aviv (Jerusalem) is against any kind of an option for the transportation of its gas reserves before guaranteeing the pipeline option.

C) Turkey-Israel Pipeline: The third option on this issue is the construction of a gas pipeline between Turkey and Israel (see Map V). In the past years, several negotiations were made on the implementation of this pipeline (Kisacik and Erenel 2019: 55-56). When all these three options' cost-benefit analyses are taken into account, the most economically feasible and the highest profitable option is by far the Turkish-Israel Pipeline.

D) The Most feasible option: According to Oslo Peace Institute, the total cost of East-Med stands projected as 16 billion Euros. When it is operated, the total income stands envisioned as 44.7 billion Euros. Again, according to the estimations of the Oslo Peace Institute, the total possible cost of the 
LNG option remains projected as 10.3 billion Euros, whereas the total profit stays foreseen as 41.1 billion Euros. According to the same institution's calculations, the Turkish-Israeli Pipeline stands projected to cost as 4 billion Euros, and the total income stands anticipated as 56.8 billion Euros if this pipeline becomes operative (Kisacik and Erenel 2019: 56-57). Thus, the most feasible option for Eastern Mediterranean natural gas resources seems to be -by far- Turkey-Israel Pipeline. However, due to the ongoing political dispute between Ankara and Tel-Aviv (Jerusalem), as well as social tensions, political risks might overshadow economic rationale.

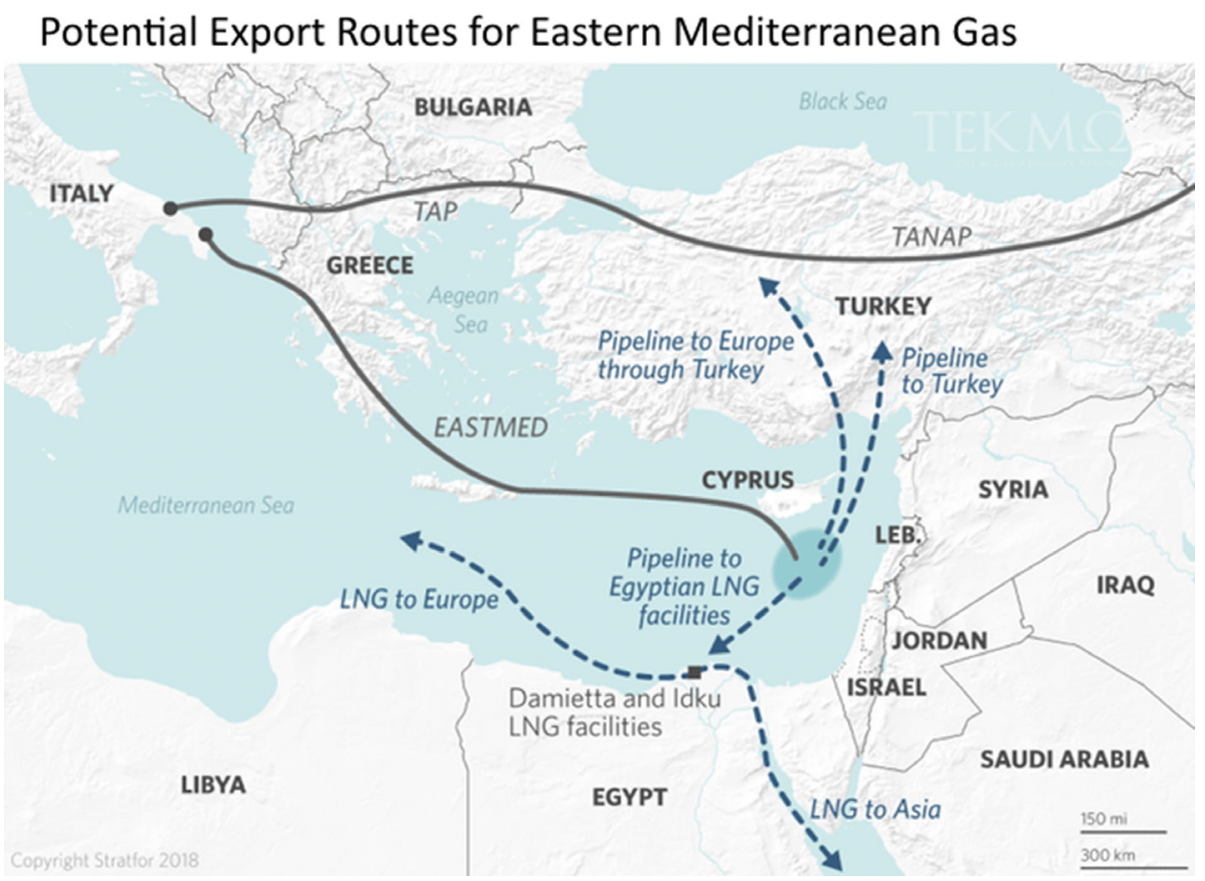

Map 5. Potential Export Routes for Eastern Mediterranean Gas (Scimia 2019)

As of January 24, 2020, according to the Energy Reporters, the EU has organized travel bans and asset freezes over individual Turks, nonetheless stand hitherto to label them to give Turkey's nationalist administration time for ending its drilling missions. For the analysis, if the Turkish drill-ships discover natural gas reserves nearby the divided island, it will be aggravating for Turkey to conciliate regarding the issue. According to the analysis, South Cyprus is supposedly filibustering EU 
sanctions counter to numerous Russian figures in Crimea in an outward effort to insist on stronger action contrary to Turkey's drilling for gas. In this analysis, it is stated that the EU sanctions concerning Crimea necessitate united support from member states. When it is examined from this perspective, the blockage of South Cyprus has been evaluated by an EU diplomatic source as The way Cyprus is hijacking the Russian listings has deeply irritated its friends and partners around the table. It is all the more surprising since Cyprus has enjoyed unparalleled solidarity from its EU partners over the last few months (Energy Reporters 2020). These accusations have been rejected by Greek Cypriot administration's government spokesman Kyriakos Koushos as:

There is no connection made between the two sanctions regimes. We are in the process of reviewing the information provided with regard to the Ukraine sanctions. Cyprus has retreated from an accusation that Turkey may have seized data to pinpoint a target for gas drilling inside the republic's exclusive economic rights. No data theft had occurred, and the word "stolen" had been "a slip of the tongue. Turkey details to send one of its drill-ships to maritime Block 8 licensed by Cyprus to Italy's ENI and Total of France" (Energy Reporters 2020).

\subsection{The Militarization of the Conflict}

Within this framework, it is also understood that countries review their naval power settings in line with their initiatives in the Eastern Mediterranean. When the NATO activities are too involved within this picture, 71 warships from 19 countries remain keenly situated within the region right now. When the constant upsurge in the quantities along with the mobilization is taken into consideration, as specified by Alfred Mahan, the states vigorously enjoy their naval powers to realize their hegemonic goals (Çomak and Şeker 2019: 1500). It ought to be deliberated in this manner that, as said by the National Defence Ministry of Republic of Turkey on June 23, 2019, Turkish Fatih and Yavuz deep-sea drilling vessels and Barbaros Hayrettin Paşa Seismic Vessel that have been operating at the Eastern Mediterranean are protected by the Turkish Naval Forces. As stated by the Ministry, the Naval Forces make the full shield of Turkey's drilling ships throughout the sea plus under the water highlighting that the defensive drones, planes, helicopters, corvettes, frigates, and submarines are ready for the involvement when it is required (Daily Sabah 2019). As an important component of Turkey's initiatives defending both its and 
TRNC's rights derived from the international law in terms of Cyprus, Ankara has decided to set up a drone base in Northern Cyprus. Within this context, Bayraktar TB2 armed unmanned aerial vehicles from Naval Air Command in Dalaman, Aegean Turkey, would land in TRNC at 10 a.m. (0700GMT) in the aftermath of coming a green light from the Turkish Cypriot government on December 16, 2019 (Kazanc1 2019).

In this part of the paper, two separate analyses from the different universities in Turkey will be shared to ensure a better understanding of Ankara's firm stance on this issue. The first assessment has come from Murat Aslan, a researcher on security issues for the Foundation for Political, Economic and Social Research (SETA), a Turkish think-tank and the faculty member at Hasan Kalyoncu University in Turkey. Aslan considers this initiative as having both political and technical scopes. Aslan underscores that technically, this initiative is a must for Turkey to safeguard its vessels positioned in the region. Aslan too underlines that it stands of great priority for Turkey to launch equipment within the medium of TRNC's continental waters wherein Turkey can act and instantly and concurrently detect every section of the region. Aslan stresses that accessing the area from airports located at Dalaman or else Turkey's southeastern province of Adana will be time-consuming and exhausting resources gone from the Turkish military's operative activities (Kazanc1 2019).

The second evaluation has been made by Professor Nurşin Ateşoğlu Güney, a member of Turkey's Presidential Security and Foreign Policy Council. Güney addresses that Turkey's initiative stands significant for the vessels' security within the waters nearby northern Cyprus. Moreover, it is correspondingly stressed by Güney that, up until now, Turkey was carrying out operations, specifically watching or information centered out of Dalaman. Güney points out that this initiative of Ankara will enhance the agility of these activities as well as ensure security. According to Güney, this move keeps up the safety along with information collecting and scrutiny activities of the Turkish Navy, which is supporting in the drilling activities in which this initiative should be read as a significant message for the Greek Cypriot administration. On the other hand, Professor Güney has emphasized the fact that following this move of Turkey, the U.S. Senate may well act to abandon the 1987 arms embargo on Southern Cyprus. She has also emphasized in this context that If this embargo is lifted, it would encourage Southern Cyprus to arm itself and exacerbate instability 
in the region as well as hurt peace talks referring to the decades-long, on-and-off peace talks between the two sides of the island (Kazanc1 2019).

Against these initiatives of Turkey, Greece and the Greek Cypriot administration have not been hesitating to search for security options against Turkey. One of these initiatives is the support of the EU through military power. For instance, the EU has decided to enhance its security cooperation with the PESCO (Permanent Structured Organization) initiative in 2017. This initiative has 25 EU member states, including Greece and Greek Cypriot administration (PESCO). As part of this organization, the sending of French and German naval forces to the region is thought, in addition to financial assistance considered for Greek Cypriot administration. The organization was referred to in the Greek Cypriot media as "The Protection Shield Agreement for Cyprus" (Kisacik and Erenel 2019: 65-67).

Greek Cypriot administration wants to strengthen its position against Turkey also by developing cooperation in terms of its bilateral relations with other states. One of these initiatives has been the signing of a military cooperation agreement between the Defence Ministers of Greek Cypriot administration and France (Gouvernement.fr 2018), on May 15, 2019 (Xinhuanet 2019). According to this agreement, France has acquired the right to use Evangelos Florakis Naval Base (see Map VI) located in the Mari region of South Cyprus. Moreover, it has been declared that this naval base will be modernized in a way to enable constantly stationing of French Navy in the region. Among the articles of this deal, the necessary financial support will be provided by Paris. Together with the agreement, free mobilization of French Charles de Gaulle aircraft carrier is aimed at. According to another article in the agreement, the French Navy especially commits on the protection of the ships exploring hydrocarbons that belonged to TOTAL around Cyprus. Also, for this agreement, France and the Greek Cypriot administration will be cooperating against the activities of the Turkish Navy in the region. Within the context of this deal, it is stated that France will also examine the conditions in the military bases located at the Greek part of the island, will assist in the modernization of weaponry systems of Greek National Guard Army, and will increase the numbers of joint exercises (Ekathimerini 2019). However, this agreement means the open violation of Security and Guarantee Agreements that established the Cyprus Republic of 1960. Furthermore, France has provided the Greek Cypriot administration's membership into the PESCO as well as its participation in 8 programs within this 
initiative. The modernization of Mari Naval Base (Naval News 2019) under the EU support is targeted to be completed in 2021. As the latest development regarding this issue, on January 29, 2020, Greece's Prime Minister, Kyriakos Mitsotakis, has greeted the French decision to ship war frigates to the Eastern Mediterranean as an impasse with Turkey regarding regional energy resources deepens. With rigidities between Athens and Ankara triggering upward international alarm, Mitsotakis has defined the vessels as "guarantors of peace" and underscored that The only way to end differences in the Eastern Mediterranean is through international justice. Greece and France are pursuing a new framework of strategic defence. Mitsotakis was there in the French capital on a visit intended to gathering EU backing at a time when antagonistic relationships with Turkey have concealed all other matters on the agenda of his approximately seven-month-old government. French President Emmanuel Macron, on the other hand, has assured that France will boost its strategic link with Greece, blaming Turkey of not only worsening regional rigidities but also fading to stick to its guaranteed course of action in war-torn Libya. Macron commented as follows:

I want to express my concerns about the behaviour of Turkey at the moment... We have seen during these last days Turkish warships accompanied by Syrian mercenaries arrive on Libyan soil. This is an explicit and serious infringement of what was agreed [at last week's peace conference] in Berlin. It's a broken promise" (Smith 2020).

Most recently, two French Rafale jets flew over South Cyprus on February 2, 2020, to show French presence on the island (Kibris Gazetesi 2020).

In addition to these developments, Greece has also increased its military operational exercises with the Greek Cypriot administration in terms of land, and the former has pursued land and air exercises with Israel. In addition to this, the establishment of an army protecting the seas in the name of safeguarding the quasi EEZs between Israel and the Greek Cypriot administration has been decided in 2012 and has been agreed to ensure this via submarines and torpedoes. In line with this, Egypt has also chosen to deepen military cooperation with the Greek Cypriot administration. Within this context, Cairo has increased the multinational military exercises like Medusa 6 and Arab Shield- 1 in the sea fields as well as has begun to construct 3 naval bases to protect its so-called EEZs, which have been conflicting with Turkey (Kisacik and Erenel 2019: 68-69). 


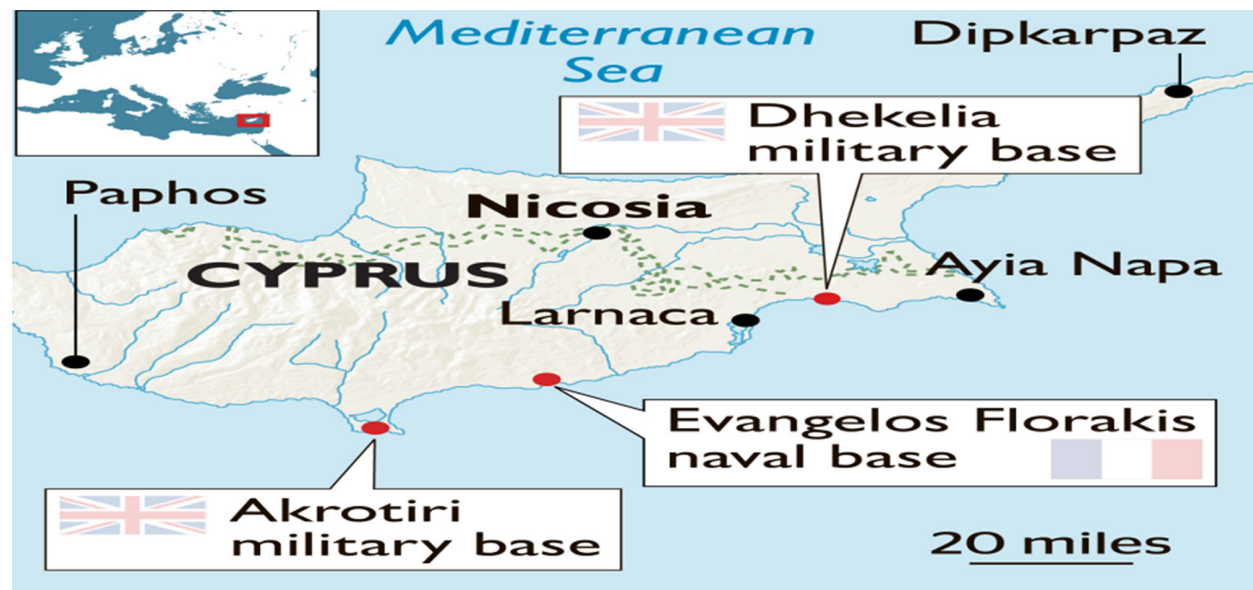

Map 6. Military bases in Cyprus (Kington and Fisher 2019)

On the other hand, the U.S. also started a rapprochement process with Nicosia in recent months. For instance, according to "H.R.1865 - Further Consolidated Appropriations Act, 2020" law introduced by Republican representative Bill Pascrell, U.S. arms embargo towards Greek Cypriot administration (Cyprus Republic) - which has been in effect since 1987 - was recently removed by Washington (U.S. Congress) ${ }^{16}$. TRNC Foreign Ministry and Deputy Prime Ministry condemned this decision (Arslan 2019), while Turkey also criticized the decision and assessed U.S. policy as an effort to hamper solution in the Island of Cyprus and cooperation opportunities in the Eastern Mediterranean by underlining the block on the delivery of F-35 aircraft to Turkey (Republic of Turkey Ministry of Foreign Affairs 2019).

\subsection{Russian Position on Eastern Mediterranean}

Within this context, it is vital to understand how the Russian Federation approaches to these developments in terms of political, economic, energy, and security dimensions since Moscow has transformed into a game-changer in the Eastern Mediterranean after its successful military

16 “Title II - Eastern Mediterranean Security and Energy Partnership Sec. 203. (6) It is the policy of the United States to support deepened security cooperation with the Republic of Cyprus through the removal of the arms embargo on the country". See: U.S. Congress. 
intervention into Syria in 2015. Moscow willingly stimulates the Greek Cypriot administration's proclamations of sovereignty over the continental shelf and natural resources of the island. Even in 2011, when there was no Syria or Crimea disagreement between Turkey and Russia, when there were severe debates regarding the sea authorization zones between Ankara and Nicosia, Kremlin sent a group of warships (one of them was Admiral Kuznetsov aircraft carrier) to offshore Cyprus Island to support Nicosia. This policy of Russia was warmly welcomed by the Greek Cypriot administration as a safeguard against the threats coming from Turkey. The Russian backing stands likewise valued unquestionably by Greece and Israel en bloc. The single naval base of Moscow in the Mediterranean stands positioned in Tartus, Syria.

The ongoing civil war in Syria and the qualms vis-à-vis the future of the Bashar al Assad regime, a close ally of the Russian Federation, have further increased the strategic repercussion of Greek Cypriot administration for Russia. As a result of long diplomatic efforts, Moscow and Nicosia have signed a military deal concerning the allowance of former's benefiting from the latter's ports in February 2015. In return to this, Russia obliged for reshuffling its 2.5 billion Euros aid given to the Greek Cypriot administration in 2011. Besides, Greek Cypriot leader Nicos Anastasiadis objected to EU sanctions against Russia during his Moscow visit in which the above-mentioned agreement was signed and guaranteed the increase of military cooperation between these two states (Hasanoğlu and Abbasov 2019: 803-818; Kisacik 2019: 911-935).

Here, it should be pointed out that one of the most important issues prioritized by Moscow to be able to show its effectiveness in the Black Sea Basin (Tüysüzoğlu 2019: 81-91; Kisacik 2018: 146-150, 153-162) has been the armament. Moscow's military plans and armament program toward this region are considered within the context of the country's "South Military Zone". This region is one of the five great military districts of the country, and it is perceived as the smallest one in terms of the area that it covers. The South Military District comprises of Southwest Russia, Northern Caucasia, Caspian, and the region at the Black Sea shore that has been including the Crimea since 2014. The process of the 2014 Ukraine Crisis and later on the Crimean invasion has increased the awareness towards the "South Military District" of Russia. Following this, when Moscow has begun to follow alterations in its military plans regarding the region, it has decided the modernization of Black Sea Fleet, the 
renewal of naval bases located at the Black Sea coast as well as making new investments in Crimea. As of 2017, Russia has stationed 28.000 soldiers to Crimea, and most of them are the naval elements under its Black Sea Fleet. The Black Sea Fleet has been one of the most significant military elements inherited by Russia from the Soviet Union. The responsibility field of the Black Sea Fleet covers the Mediterranean in addition to the Black Sea. It can be mentioned that the Russian naval forces located even at Syria and the Eastern Mediterranean, in general, are composed of the elements linked to the Black Sea Fleet and South Military District (see Map 7) (Tüysüzoğlu 2019: 86).

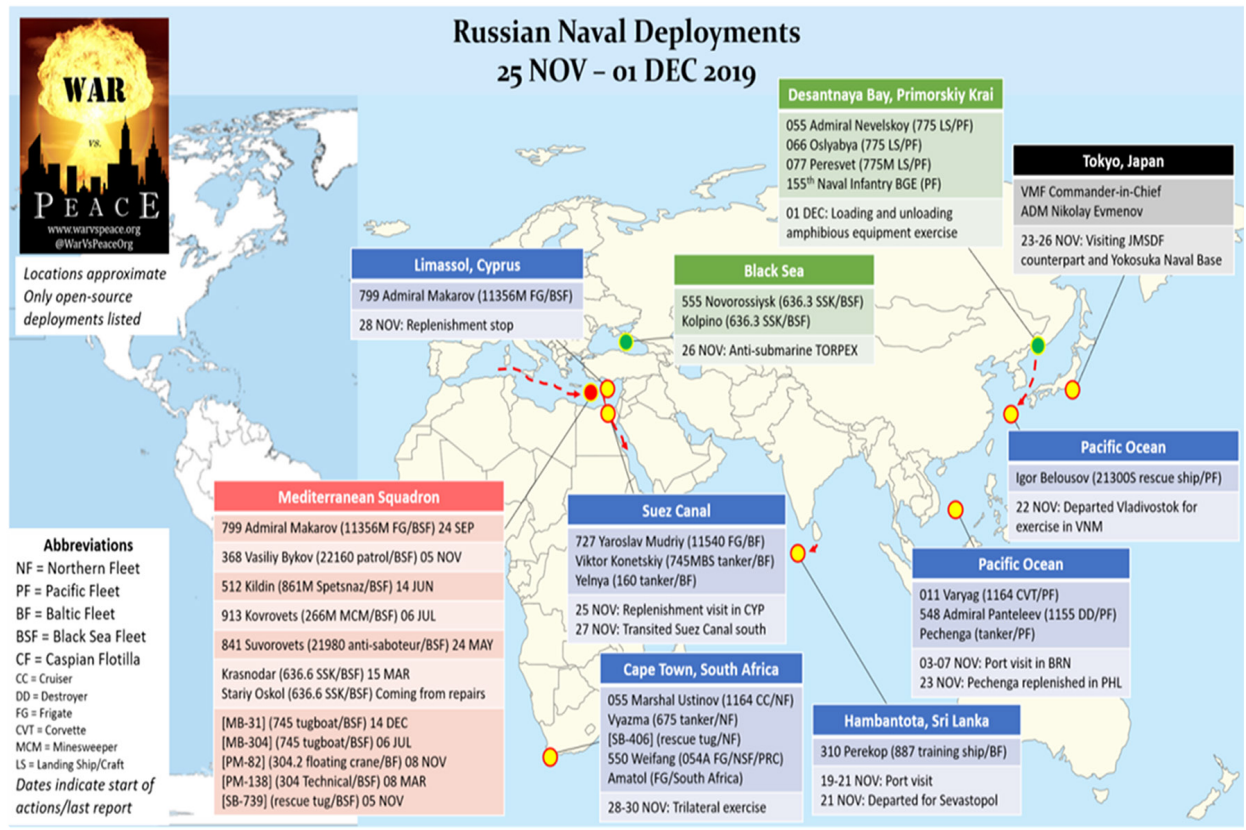

Map 7. Russian Naval Deployments: 25 November-1 December 2019 (War \& Peace 2019)

However, the latest sanctioning decision of Brussels inthe latest EU Foreign Affairs Council's declaration on July 15, 2019 toward Ankara due to the latter's recent undertakings in the East-Med was criticized by Moscow. On July 17, 2019, Russian Foreign Ministry spokeswoman Maria Zakharova voiced her country's official posture concerning this subject as; 
Sanction is not "a tool of diplomacy", and it cannot be a basis of international politics. Therefore, we have an extremely negative attitude towards any sanctions that are not authorized by the [UN] Security Council. As a reciprocal measure, we are forced to say that it is a part of the modern reality. But we cannot accept such a unilateral, illegal, aggressive pressure and policy that aims at promoting one's interests [...] (Teslova 2019; TASS - Russian News Agency 2019).

In line with energy-based cutting-edge developments in the East-Med recently, it stays remarkable to point out the forward-looking proclamations of Russian Energy Minister Alexandr Novak regarding this subject. In an exclusive talk made with him by the Anatolian Agency on July 26, 2019, before the 16th term Turkey-Russia Joint Economic Commission Meeting, he has stressed that;

Russia is considering cooperation with Turkey in the Eastern Mediterranean if energy projects in the region are deemed commercially viable. Turkish and Russian companies may join forces for activities in the region. We give implicit support for Turkey's longstanding diplomatic efforts to bring peace to the Cypriot island and the East Mediterranean region by urging regional countries to share the riches, particularly natural gas resources [...] (TASS - Russian News Agency 2019; Asharq Al-Awsat 2019).

\section{Conclusions}

To conclude, there are important political risks that need to be addressed before the monetization of the energy reserves in the Eastern Mediterranean. The first among these political risks is the lack of a mutually-agreed EEZ between the coastal states in the region. The EEZ is an international maritime law that defines the economic privileges of states under their sea beds. When it is considered in terms of the Eastern Mediterranean, one can easily state that there is no reciprocally-compromised agreement on the delimitation of EEZ among the coastal states. Therefore, each state in this region prefers to sign an agreement with other states to delimit EEZ and then benefit from the economic resources under the sea. In this context, the Greek Cypriot administration has signed EEZ agreements with Lebanon, Israel, and Egypt at the beginning of the 2000s. Here in this context, it should be remembered that Turkey is not one of the signatory states of 1982 UNCLOS. Turkey, on the other hand, signed an EEZ agreement with 
TRNC in 2011. Moreover, most recently, Turkey signed a maritime zone agreement with the Libyan government in December 2019. Conflicting interests and clashing areas between coastal states in terms of the delimitation of maritime zones in the Eastern Mediterranean necessitates a negotiation and consensus process among the related parties for the realization of energy transportation projects. Otherwise, as it was proven by Turkish warships' recent obstruction of Italian ENI's drilling ship and French jet planes' most recent flight over Cyprus, there will always be political and security risks that might further escalate the tension within the region. Moreover, since the Russian Federation is a country that invests a lot in being a monopoly in energy politics, an alternative energy road that does not provide advantages to Moscow in the Eastern Mediterranean might not take support from Russia. The U.S., on the other hand, follows a policy towards this region to protect the interests of American energy companies as well as securing Israel, Greece, and Greek Cypriots. To achieve this, Washington plans the sale of F-35 new generation jet fighters to Greece (while blocking sales to Turkey as a response to Ankara's decision to buy an S-400 air missile defense system from Russia) and to extend necessary Foreign Military Assistance to Greece (Kelly 2019). Lastly, the European Union also wants to help Greece and Greek Cypriot administration as its members within the PESCO initiative and ignores Turkish objection due to spoiling relations with Ankara and the frozen membership process.

The second important political risk would be to further the securitization of these disagreements in the near future. As it was stated before, Greek Cypriot administration's unilateral ventures without Turkish support and recent military agreements with France might trigger further militarization within this region. Turkey, being the country with the longest shore in the Eastern Mediterranean and one of the three guarantor states of Cyprus Republic has military bases in Northern Cyprus. Turkey even decided to set up a drone base in Northern Cyprus recently to assist and protect Turkish drilling vessels in the region. It should not be forgotten that Turkey takes advantage of its Navy and Air Force presence in this region to protect its rights as well as Turkish Cypriots' rights. Moreover, having two military bases in Cyprus and being one of the three guarantor states of Cyprus Republic, United Kingdom also might have concerns for the militarization of the region by other states such as France and Russia.

Other risky issues in terms of monetization of Eastern Mediterranean energy resources -other than clashing EEZ zones and militarization of the 
region- are; non-resolution of Cyprus Dispute, ongoing Arab-Israeli Conflict (although U.S. President Donald Trump announced a new peace plan "Deal of the Century" recently), the protracted Syrian Question (Idlib issue and so on), and the Libyan Crisis. These problems force countries within this region to prioritize security policies and military alliances rather than focusing on economic interests. The militarization of these conflicts is risky for all sides, and the well-being of democracies since democracies mostly prefer diplomatic and democratic methods to resolve their confrontations, and in times of crisis and war, civilian politicians lose their power gradually.

Considering these risks, one can claim that the AK Party government will continue to use nationalism domestically and Turkey's soft and hard power instruments in the Eastern Mediterranean (primarily in Northern Cyprus) to force all sides for a negotiation process. However, the AK Party's nationalism is instrumental, and it aims to necessitate a "win-win" approach in this region. Turkey's main political target is to be a part of the developing energy game within this region and orientate the abovementioned countries to work on a feasible plan to connect Eastern Mediterranean energy resources to Southern Gas Corridor (TANAP and TAP projects). Ankara's policy is plausible since all economic indicators prove that the most feasible option for the transportation of these resources is through a pipeline to be constructed over Turkey. Western objection to Ankara's stance, on the other hand, is caused by prejudices and concerns for Turkish democracy. To avoid this, Ankara could make positive steps for democratization and could recover its relations with the U.S. and the EU. In this case, economic mentality could easily prevail, and the Eastern Mediterranean could turn into an area of economic cooperation, although political disputes within this region (such as the Cyprus Dispute and the Arab-Israeli Conflict) would not be easily solved.

\section{References}

A letter dated 20 June 2011 from the Minister for Foreign Affairs and Emigrants of Lebanon addressed to the Secretary-General of the United Nations concerning the Agreement between the Government of the State of Israel and the Government of the Republic of Cyprus on the Delimitation of the Exclusive Economic 
Zone, signed in Nicosia on 17 December 2010, https://www.un.org/Depts/ los/LEGISLATIONANDTREATIES/PDFFILES/communications/lbn_re_ cyp_isr_agreement2010.pdf (28.01.2020).

AB Haber (2018), Annan Çözüm Planı Referandumu'nun 14. Yıldönümü, http:// www.abhaber.com/annan-cozum-plani-referandumunun-14-yildonumu/ (24.01.2020)

Agreement between the Government of the State of Israel and the Government of the Republic of Cyprus on the Delimitation of the Exclusive Economic Zone, signed in Nicosia on 17 December 2010 (entry into force: 25 February 2011; registration \#:I-48387 ; registration date: 9 March 2011", https:/ /www.un.org/ Depts/los/LEGISLATIONANDTREATIES/PDFFILES/TREATIES/cyp_isr_ eez_2010.pdf (28.01.2020).

Agreement between the Republic of Cyprus and the Arab Republic of Egypt on the Delimitation of the Exclusive Economic Zone, 17 February 2003 (entry into force: 7 March 2004; registration\#: I-44649; registration date: 14 January 2008), https://www.un.org/Depts/los/LEGISLATIONANDTREATIES/ PDFFILES/TREATIES/EGY-CYP2003EZ.pdf (28.01.2020).

Ak, G. (2014), 'Sovereign British Bases on Cyprus and Their Impacts on the Maritime Delimitation in the Eastern Mediterranean', Alternatives: Turkish Journal Of International Relations, 13 (4): 59-69, https:/ / dergipark.org.tr/en/ download/article-file/19350 (29.01.2020)

AK Parti (2002), herşey Türkiye için!, https:/ / acikerisim.tbmm.gov.tr/xmlui/bitstream/handle/11543/954/200304063.pdf (26.01.2020).

AKEL, Strength comes from struggle, Hope comes from the left, https://www. akel.org.cy/en/cyprus-problem-in-brief/\#.XirHW2gzbIU (24.01.2020).

Alarçin, H.E. (2020), 'Doğu Akdeniz'de Değişen Dengeler: Türkiye-Libya Mutabakatı', Uluslararası Politika Akademisi, http://politikaakademisi. org/2020/01/01/dogu-akdenizde-degisen-dengeler-turkiye-libya-mutabakati/ (26.01.2020).

Andrews, E. (2018), 'What was the Gordian Knot?', History.com, https://www. history.com/news/what-was-the-gordian-knot (24.01.2020).

Appendix 1: Conference on Cyprus: Documents signed and initialed at Lancaster House on 19 February 1959, https:/ / www.embargoed.org/wp-content/ uploads/2018/02/1959_London_and_Zurich_-Agreements.pdf ] (24.01.2020).

Arslan, M.İ. (2019), 'KKTC'den ABD'nin Rumlara uyguladığ1 silah ambargosunu kaldırma kararına tepki', Anatolian Agency, https://www.aa.com.tr/tr/ dunya/kktcden-abdnin-rumlara-uyguladigi-silah-ambargosunu-kaldirma-kararina-tepki/1673416 (05.02.2020).

Asharq Al-Awsat (2019), Russia to Cooperate with Turkey in Oil Exploration in E. Mediterranean, https://aawsat.com/english/home/article/1845981/russia-cooperate-turkey-oil-exploration-e-mediterranean (30.01.2020). 
Bayar, G. (2020), 'East Mediterranean gas pipeline project can't succeed', Anatolian Agency (AA), https:/ / www.aa.com.tr/en/europe/east-mediterranean-gas-pipeline-project-can-t-succeed/1690732 (27.01.2020).

Bayraklı, E and H.M. Boyraz (2017), 'AB'nin Gölgesinde Türkiye'nin Kıbrıs Politikası', in K. İnat, A. Aslan and B. Duran (eds), AK Parti'nin 15 Yılı Dış Politika (İstanbul: SETA Kitaplar1): 427-448.

BBC Türkçe (2016), AB mülteci zirvesi: Türkiye - AB anlaşmaya vardı", https:// www.bbc.com/turkce/haberler/2016/03/160318_ab_turkiye_anlasma_sonuc (26.01.2020).

BBC Türkçe (2017), Kıbrıs müzakereleri sonuç çıkmadan sonlandı, https:/ / www.bbc. com/turkce/haberler-dunya-40527744 (26.01.2020).

Bozkurt, U. (2014), 'Turkey: From the Motherland to the IMF of Northern Cyprus', Cyprus Review, XXVI (2): 83-105.

Çomak, H. and B.Ş. Şeker, (2019), 'Doğu Akdeniz Enerji Jeopolitiği Çerçevesinde Devletlerarası Donanma Rekabeti ve Küresel Deniz Gücü Olma Yarışı', in H. Çomak and S.S. Burak (eds), Akdeniz Jeopolitiği Cilt II (Ankara: Nobel Akademik Yayınc1lı): 1493-1502.

Daily Sabah (2019), Turkish Navy fully protecting drilling vessels in East Med, https:/ / www.dailysabah.com/defense/2019/07/24/turkish-navy-fully-protecting-drilling-vessels-in-east-med (30.01.2020).

Deputy Prime Ministry and Ministry of Foreign Affairs, Missions Abroad, https:/ / mfa.gov.ct.tr/consular-info/missions-abroad/ (24.01.2020).

Devlet Su İşleri Genel Müdürlüğü, KKTC Su Temin Projesi, http:/ / www.dsi.gov. tr/projeler/kktc-su-temin-projesi (25.01.2020).

DW Türkçe (2004), Yeniden Birleşme Olmuyor, https:/ / www.dw.com/tr/yeniden-birle\% C5\%9Fme-olmuyor/a-2526696 (26.01.2020).

Ecevit Kıbrıs Barış Harekatını ilan ediyor!.webm, https://www.youtube.com/ watch?v=wrDQW66jWoo (25.01.2020).

Ekathimerini (2019), Cyprus, France reportedly agree on use of naval base, http:/ / www.ekathimerini.com/240536/article/ekathimerini/news/cyprus-france-reportedly-agree-on-use-of-naval-base (30.01.2020).

Ekathimerini (2020), Italy, Cyprus say Turkey-Libya maritime deal 'unacceptable', http:/ / www.ekathimerini.com/248993/article/ekathimerini/news/italy-cyprus-say-turkey-libya-maritime-deal-unacceptable (01.02.2020).

Elliott, S. (2019), 'Turkey vows to 'protect' rights to drill for gas offshore Cyprus', SEP Global, https://www.spglobal.com/platts/en/market-insights/latest-news/natural-gas/071019-turkey-vows-to-protect-rights-to-drill-for-gas-offshore-cyprus (29.01.2020).

Encyclopedia Britannica, Gordian knot, https://www.britannica.com/topic/Gordian-knot (24.01.2020). 
Energy Reporters (2020), Cyprus blocking EU's Crimea sanctions over Turkey gas dispute: sources, https://www.energy-reporters.com/production/ cyprus-blocking-eus-crimea-sanctions-over-turkey-gas-dispute-sources / (29.01.2020).

Erciyes, Ç. (2012), 'Maritime Delimitation \& Offshore Activities in the Eastern Mediterranean Legal \& Political Perspectives Recent Developments', TUROGE, http://www.mfa.gov.tr/site_media/html/maritime_delimitation.pdf (29.01.2020).

Erlanger, S. and S. Castle (2015), 'British Jets Hit ISIS in Syria after Parliament Authorizes Airstrikes', The New York Times, https:/ / www.nytimes.com/2015/12/03/ world/europe/britain-parliament-syria-airstrikes-vote.html (26.01.2020).

European Commission (2019/a), Commission publishes 4th list of Projects of Common Interest - making energy infrastructure fit for the energy union, https:/ / ec.europa. $\mathrm{eu} /$ info/news/commission-publishes-4th-list-projects-common-interest-making-energy-infrastructure-fit-energy-union-2019-oct-31_en (28.01.2020).

European Commission (2019/b), Annex to Commission Delegated Regulation (EU) ...... amending Regulation (EU) No 347/2013 of the European Parliament and of the Council as regards the Union list of projects of common interest \{SWD(2019) 395 final\} Brussels, 31.10.2019 C(2019) 7772 final, https://ec.europa.eu/energy/ sites/ener/files/c_2019_7772_1_annex.pdf (28.01.2020).

Gouvernement.fr (2018), Defence agreements between France, Albania and Cyprus: A bill authorises approval of defence cooperation agreements with Albania and Cyprus, https:/ / www.gouvernement.fr/en/defence-agreements-between-france-albania-and-cyprus (31.01.2020).

Haber7.com (2011), İşte AK Parti'nin Seçim Beyannamesi, http://www.haber7.com/partiler/haber/733934-iste-ak-partinin-secim-beyannamesi (26.01.2020).

Haberler.com (2006), Mehmet Ali Talat'ın Kupayı Vermesinin Faturası 5 Milyon Dolar, https://www.haberler.com/mehmet-ali-talat-in-kupayi-vermesinin-faturasi-5-haberi/ (26.01.2020).

Hamit, D. (2020), 'Turkey rebukes Italy over comments on East Med', Anatolian Agency, https://www.aa.com.tr/en/politics/turkey-rebukes-italy-over-comments-on-east-med/1719306 (01.02.2020).

Hasanoğlu, İ. and E. Abbasov (2019), 'Rusya Federasyonu'nun Akdeniz Politikasında Kıbrıs', in H. Çomak and S.S. Burak (eds.), Akdeniz Jeopolitiği Cilt I (Ankara: Nobel Akademik Yayıncılık): 803-818.

Hürriyet (2002), İşgalci konumuna düşeriz, http:/ / www.hurriyet.com.tr/gundem/ isgalci-konumuna-duseriz-116182 (26.01.2020).

Hürriyet (2018), Kıbrı'ta 110 bin Türk Rum vatandaşı oldu, http://www.hurriyet.com.tr/gundem/kibrista-110-bin-turk-rum-vatandasi-oldu-40791422 (26.01.2020). 
Hürriyet (2019), Erdoğan: Kıbrıs Türklerinin Doğu Akdeniz'deki haklarmı gasp

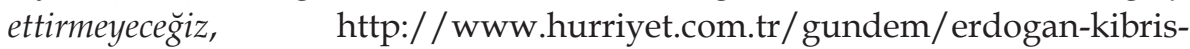
-turklerinin-dogu-akdenizdeki-haklarini-gasp-ettirmeyecegiz-41374454 (26.01.2020).

IGI Poseidon, Eastmed, http:/ / www.igi-poseidon.com/en/eastmed (26.01.2020). Işıksal, H. (2015), 'The Four Stages of Turkish Position in Cyprus: The Elements of Continuity and Change', in O. Örmeci and H. Işıksal (eds), Turkish Foreign Policy in the New Millennium (Frankfurt am Main: Peter Lang): 297-312.

Işıksal, H. (2016), ‘Türkiye-Güney Kıbrıs Rum Yönetimi (Kıbrıs Cumhuriyeti) İlişkileri: Geçmişin Prangaları Arasında Gelecek Arayışları', in O. Örmeci and H. Işıksal (eds), Mavi Elma: Türkiye-Avrupa İlişkileri (Ankara: Gazi Kitabevi): 257-274.

Kazanc1, H. (2019), 'Turkish drone move necessary for security: Experts', Anatolian Agency, https://www.aa.com.tr/en/europe/turkish-drone-move-necessary-for-security-experts/1675989 (29.01.2020).

Kelly, L. (2019), 'Congress looks to Mediterranean allies to counter Turkey, Russia', The Hill, https://thehill.com/policy/international/475827-congress-looks-to-mediterranean-allies-to-counter-turkey-russia (05.02.2020).

Kesgin, S. (2018), Küresel ve Bölgesel Perspektiften Doğu Akdeniz Güvenliği (Ankara: Berikan Yayınevi).

Kıbrıs, G. (2020), Fransız savaş uçakları Güney Kıbrıs üzerinde uçtu, https://www. kibrisgazetesi.com/kibris/fransiz-savas-ucaklari-guney-kibris-uzerinde-uctu-h82120.html (05.02.2020).

Kisacık, S. (2018), 'Türkiye-Rusya Federasyonu İlişkileri', in G. Tüysüzoğlu and A. Özkan (eds), Soğuk Savaş Sonrası Türkiye'nin Kafkasya ve Orta Asya Siyaseti (Ankara: Detay Yayıncilık): 133-222.

Kısacık, S. (2019), '21. Yüzyılda Avrasya Enerji Jeopolitiği' nin Potansiyel Yeni Y1ldızı Doğu Akdeniz' de Enerji Güvenliğinin Temel Parametreleri', in H. Çomak and B.Ş. Şeker (eds), Akdeniz Jeopolitiği Cilt II (Ankara: Nobel Akademik Yayıncllik): 977-1015.

Kısacık, S. (2019), 'Bağımsız Devletler Topluluğu'nun Akdeniz Politikaları Çerçevesinde Bir Vaka Çalışması Olarak Suriye Meselesi', in H. Çomak and B.Ş. Şeker (eds), Akdeniz Jeopolitiği CiltII (Ankara: Nobel Akademik Yayıncılık): 911-935.

Kısacık, S. (2020), ‘Doğu Akdeniz Enerji Jeopolitiği Çerçevesinde Türkiye-Libya Mutabakatı ve East-Med Anlaşmasını Anlamlandırmak', Uluslararası Politika Akademisi, http://politikaakademisi.org/2020/01/09/dogu-akdeniz-enerji-jeopolitigi-cercevesinde-turkiye-libya-mutabakati-ve-eastmed-anlasmasini-anlamlandirmak/ (28.01.2020).

Kısacık, S. and F. Erenel (2019), 'Doğu Akdeniz Güvenlik Algılamaları Bağlamında, Kalıcı Yapılandırılmış İşbirliği Savunma Anlaşması (The Permanent 
Structured Cooperation-PESCO) ve Enerji Güvenliği Meselelerinin Avrupa Birliği-Türkiye İlişkilerine Olası Yansımalarını Anlamak', Türkiye Siyaset Bilimi Dergisi, 2(1): 51-76, https:/ / dergipark.org.tr/tr/download/article-file/856440 (30.01.2020).

Kistak, S. (2019), 'Eastern Mediterranean gas: Why Turkey is key to its success', Hürriyet Daily News, https:/ / www.hurriyetdailynews.com/eastern-mediterranean-gas-why-turkey-is-key-to-its-success-148668 (27.01.2020).

Kington, T. and L. Fisher (2019), 'Cyprus seeks French military help in snub to 'distracted' UK', The Times, https://www.thetimes.co.uk/edition/news/ cyprus-seeks-french-military-help-in-snub-to-distracted-uk-xsfhx795q (30.01.2020).

KKTC Enformasyon Dairesi (2018), Bakan Özersay Chatham House'da konuşma yaptl, https://pio.mfa.gov.ct.tr/bakan-ozersay-chatham-houseda-konusma-yapti/ (26.01.2020).

KKTC Enformasyon Dairesi (2019), ‘Dışişleri Bakanı Mevlüt Çavuşoğlu: Kıbrıs Rum tarafı ne iddia ederse etsin Kıbrılı Türklerle iktidar ve refahı paylaşmak istemiyor', https:// pio.mfa.gov.ct.tr/disisleri-bakani-mevlut-cavusoglu-kibris-rum-tarafi-ne-iddia-ederse-etsin-kibrisli-turklerle-iktidar-ve-refahi-paylasmak-istemiyor / (26.01.2020).

Maritime Boundary Office, The Law of the Sea, http:/ / www.gfm.tl/learn/the-law-of-the-sea/ (28.01.2020).

Mehmet, F.H. (2020), 'EastMed gas pipeline 'political project': Expert', Anatolian Agency, https://www.aa.com.tr/en/europe/eastmed-gas-pipeline-political-project-expert/1691197 (27.01.2020).

MHP AR-GE Merkezi (2003), Haysiyet ile Teslimiyetçiliğin Mücadelesi: KIBRIS GERÇEĞİ ve ANNAN PLANI, https:/ / www.mhp.org.tr/usr_img/_mhp2007/ files/raporlar/kibris/kibrisraporu.pdf (26.01.2020).

Michalopoulos, S. (2020), 'EU welcomes EastMed gas pipe deal as 'one option' to strengthen energy security', Euractiv, https:/ / www.euractiv.com/section/ energy/news/eu-welcomes-eastmed-deal-but-highlights-further-cost-benefit-analysis/ (27.01.2020).

Milli Gazete (2008), Denktaş: Kıbrıs batmayan uçak gemisi, https:/ / www.milligazete. com.tr/haber/794329/denktas-kibris-batmayan-ucak-gemisi.

Naval News (2019), Cyprus Plans Mari Naval Base Expansion to Host French Navy Ships, https://www.navalnews.com/naval-news/2019/05/cyprus-plans-mari-naval-base-expansion-to-host-french-navy-ships/ (30.01.2020).

Örmeci, O. (2015), 'Cyprus Dispute in Terms of Energy Politics', in O. Örmeci and H. Işıksal (eds), Turkish Foreign Policy in the New Millennium (Frankfurt am Main: Peter Lang): 325-335. 
Örmeci, O. and S. Kısacık (2019), '2002-2017 Döneminde Kıbrıs Sorunu ve Türk Dış Politikass: Gordion Dügüumü Henüz Çözülemedi', in S. Kekevi and Ö. Kurtbağ (eds), Türk Dış Politikası 2000'li Yıllar (Ankara: Berikan Yayınevi):. 47-116.

Öztürk, Y.N. (2005), 'KUR'AN Verileri Işığında AB-AKP Siyasetlerine Bir Bakış: Prof. Dr. Yaşar Nuri Öztürk', Türk Lider, http://www.turklider.org/TR/ EditModule.aspx?TabId=250\&mid=1470\&ItemId $=1318$.

PESCO, About PESCO, https:/ / pesco.europa.eu/ (05.02.2020).

Presidency of the Republic of Turkey (2020), We aim to make Turkey a global energy hub, https://www.tccb.gov.tr/en/news/542/115220/-we-aim-to-make-turkey-a-global-energy-hub- (27.01.2020).

Psaropoulos, J. (2020), 'Greece, Israel, Cyprus, move to build East Med gas pipeline', Al Jazeera, https:/ / www.aljazeera.com/news/2020/01/greece-israel-cyprus-move-build-east-med-gas-pipeline-200102181235607.html (27.01.2020).

Republic of Turkey Ministry of Foreign Affairs (2019), QA-78, 20 December 2019, Statement of the Spokesperson of Ministry of the Foreign Affairs, Mr. Hami Aksoy, in Response to a Question Regarding the Approval by the U.S. Congress of Draft Appropriations Bills, http://www.mfa.gov.tr/sc_-78_-abd-kongresinde-kabul\%20edilen-tahsisatlar-yasa-tasarilari-hk-sc.en.mfa (05.02.2020).

Republic of Turkey Ministry of Foreign Affairs (2020), QA-8, 30 January 2020, Statement of the Spokesperson of Ministry of Foreign Affairs, Mr. Hami Aksoy, in Response to a Question Regarding the Joint Statement of the Ministers of Foreign Affairs of Italy and Greek Cypriot administration on the Eastern Mediterranean, http://www.mfa.gov.tr/sc_-8_-italya-ve-gkry-db-lerin-dogu-akdeniz-aciklamalari-hk-sc.en.mfa (01.02.2020).

Reuters (2018), Cyprus accuses Turkey of blocking ship again in gas exploration standoff, https://www.reuters.com/article/us-cyprus-natgas-turkey/cyprus-accuses-turkey-of-blocking-ship-again-in-gas-exploration-standoff-idUSKCN1G71MF (26.01.2020).

Rose, C. (2020), 'For Turkey, a New Chapter in an Old Rivalry', Real Clear World, https://www.realclearworld.com/articles/2020/01/12/for_turkey_a_new_ chapter_in_an_old_rivalry_212200.html (29.01.2020).

Scimia, E. (2019), For Italy's Ruling Nationalists, Energy Security More Important Than Putin's Friendship, Tha Jamestown Foundation, https://jamestown. org/program/for-italys-ruling-nationalists-energy-security-more-important-than-putins-friendship/ (29.01.2020).

Sezer, S., Greek Oil Exploration Licences and Economic Zone Agreements in Eastern Mediterranean, http:/ / www.rieas.gr/images/sezer.pdf (29.01.2020). Smith, H. (2020), 'France to send warships to support Greece in Turkish standoff', The Guardian, https://www.theguardian.com/world/2020/jan/29/greece-turkey-standoff-france-send-warships-east-mediterranean (01.02.2020).

Şimşir, B.N. (2004), AB, AKP ve Kıbrıs (Ankara: Bilgi Yayınevi). 
T24 (2015), Çipras'tan 'Kıbrıslı Türk' açılımı, https://t24.com.tr/haber/ciprastan-kibrisli-turk-acilimi,285753 (05.02.2020).

Talat, M.A. (2012), Kıbrıs Rum Tarafıyla Hangi Konularda Anlaşmıştık?, https:// mehmetalitalat.wordpress.com/2012/10/03/kibris-rum-tarafiyla-hangi-konularda-anlasmistik/ (26.01.2020).

TASS - Russian News Agency (2019/a), Russian envoy slams EU sanctions against Turkey, https:// tass.com/world/1068919 (30.01.2020).

TASS - Russian News Agency (2019/b), Russia, Turkey may start joint exploration in offshore Mediterranean, https://tass.com/economy/1070528 (30.01.2020).

Teslova, E. (2019), ‘Russia slams European sanctions against Turkey: Russian Foreign Ministry spokeswoman Maria Zakharova says Russia cannot accept policy of sanctions', Anatolian Agency, https://www.aa.com.tr/en/politics/ russia-slams-european-sanctions-against-turkey/1534686 (30.01.2020).

The Annan Plan for Cyprus, http://www.hri.org/docs/annan/ (26.01.2020).

TRT World (2019), Why did Turkey sign a maritime deal with Libya?, https://www. trtworld.com/turkey/why-did-turkey-sign-a-maritime-deal-with-libya-32064 (30.01.2020).

Türkiye Cumhuriyet Dışişleri Bakanlığı, AB Katılım Müzakereleri, http://www. mfa.gov.tr/ab-katilim-muzakereleri.tr.mfa (26.01.2020).

Türkiye Cumhuriyeti Dışişleri Bakanlığı, Dışişleri Bakanları Listesi, http://www. mfa.gov.tr/_disisleri-bakanlari-listesi.tr.mfa (26.01.2020).

Türkiye Cumhuriyet Dışişleri Bakanlığı, Kıbrıs Konusunda Türkiye'nin Yeni Açılımı, http:// www.mfa.gov.tr/kibris-konusunda-turkiye_nin-yeni-acilimi-.tr.mfa (26.01.2020).

Türkiye Cumhuriyeti Ticaret Bakanlığı, Dış Ticaret, https:/ / ticaret.gov.tr/yurtdisi-teskilati/orta-dogu-ve-korfez/KKTC/ulke-profili/dis-ticaret (25.01.2020).

Tüysüzoğlu, G. (2019), 'Rusya' nın Karadeniz Stratejisi: Sebepler ve Uygulamalar', in G. Tüysüzoğlu and S. Kurt (eds), Uluslararası Politikada Karadeniz (Ankara: Detay Yayıncilik): 67-96.

UN Cyprus Talks, http:/ / www.uncyprustalks.org/ (24.01.2020).

U.S. Congress, H.R.1865 - Further Consolidated Appropriations Act, 2020, https:/ / www.congress.gov/bill/116th-congress/house-bill/1865/text?q=\%7B $\% 22$ sea rch $\% 22 \% 3 \mathrm{~A} \% 5 \mathrm{~B} \%$ 22Eastern+Mediterranean+Security+and+Energy+Partners hip+Act+of+2019\%22\%5D\%7D\&r=3\&s=2 (05.02.2020).

U.S. Department of the Interior / U.S. Geological Survey (2010/a), World Petroleum Resources Project: Assessment of Undiscovered Oil and Gas Resources of the Levant Basin Province, Eastern Mediterranean Fact Sheet 2010-3014, https:// pubs.usgs.gov/fs/2010/3014/pdf/FS10-3014.pdf (28.01.2020).

U.S. Department of the Interior / U.S. Geological Survey (2010/b), World Petroleum Resources Project: Assessment of Undiscovered Oil and Gas Resources 
of the Nile Delta Basin Province, Eastern Mediterranean Fact Sheet 2010-3027, https:/ / pubs.usgs.gov/fs/2010/3027/pdf/FS10-3027.pdf (28.01.2020).

War \& Peace (2019), Russian Navy Today: Russia November 2019 Naval Deployments, https:/ / www.warvspeace.org/ 2019-nov-naval-deployments (03.02.2020).

Xinhuanet (2019), Cyprus, France upgrading military relations: minister, http:/ / www. xinhuanet.com/english/europe/2019-03/04/c_137866394.htm (30.01.2020).

Yaka, Ö. (2011), 'Ulusal Dava'dan 'Ayakbağı'na: Kıbrıs Siyasetinin Dönüşümü', Memleket Siyaset Yönetim, 16 (6): 71-115.

Zontur, E.C. (2019), 'Map delineates Turkey's maritime frontiers in E.Med', Anatolian Agency, https:/ / www.aa.com.tr/en/infographics/map-delineates-turkeys-maritime-frontiers-in-emed/1661791 (28.01.2020). 